\title{
Achieving Shared Triple Bottom Line (TBL) Value Creation Toward a Social Resource-based View (SRBV) of the Firm
}

Tate, Wendy; Bals, Lydia

Document Version

Accepted author manuscript

Published in:

Journal of Business Ethics

DOI:

10.1007/s10551-016-3344-y

Publication date:

2018

License

Unspecified

Citation for published version (APA):

Tate, W., \& Bals, L. (2018). Achieving Shared Triple Bottom Line (TBL) Value Creation: Toward a Social Resource-based View (SRBV) of the Firm. Journal of Business Ethics, 152(3), 803-826.

https://doi.org/10.1007/s10551-016-3344-y

Link to publication in CBS Research Portal

\section{General rights}

Copyright and moral rights for the publications made accessible in the public portal are retained by the authors and/or other copyright owners and it is a condition of accessing publications that users recognise and abide by the legal requirements associated with these rights.

Take down policy

If you believe that this document breaches copyright please contact us (research.lib@cbs.dk) providing details, and we will remove access to the work immediately and investigate your claim. 


\section{Achieving Shared Triple Bottom Line (TBL) Value Creation: Toward a Social Resource-based View (SRBV) of the Firm Wendy Tate and Lydia Bals Journal article (Post print version)}

CITE: Achieving Shared Triple Bottom Line (TBL) Value Creation: Toward a Social Resource-based View (SRBV) of the Firm. / Tate, Wendy; Bals, Lydia. In: Journal of Business Ethics, 18.10.2016.

The final publication is available at Springer via http://dx.doi.org/10.1007/s10551-016-3344-y

Uploaded to Research@CBS: May 2017 


\title{
Achieving Shared Triple Bottom Line (TBL) Value Creation: Toward a Social Resource-Based View (SRBV) of the Firm
}

\author{
Wendy L. Tate \\ University of Tennessee \\ Lydia Bals \\ University of Applied Sciences Mainz; \\ Copenhagen Business School
}

\section{Please see final version:}

Tate, W.L., \& Bals, L. (Forthcoming): Achieving Shared Triple Bottom Line (TBL) Value Creation: Toward a Social Resource-Based View (SRBV) of the Firm, Journal of Business Ethics.

\begin{abstract}
Whereas the economic and environmental dimensions of the triple bottom line (TBL) have been covered extensively by management theory and practice, the social dimension remains largely underrepresented. The Resource-based View (RBV) of the firm and the Natural Resource-based View (NRBV) of the firm are revisited to lay the theoretical foundation for exploring how the social dimension might be addressed. Social capabilities are then explored by looking at the social entrepreneurship literature and illustrative cases with the purpose of elaborating RBV toward a Social Resource-based View (SRBV) of the firm. Three illustrative cases, which represent social businesses located in catastrophe-ridden Haiti, show how capabilities are used to overcome challenging constraints. The goal for the social entrepreneur is to employ the appropriate capabilities to ensure economic success, a positive environmental impact, and social benefits that leave the local community in a better position than without the business. Just as NRBV is a previous elaboration of RBV, so can SRBV be an elaborated theoretical foundation for future research. The components of a theory are systematically addressed by extending the range of variables (adding social capabilities), extending the domain (including stakeholders with economic, environmental and/or social stakes), and offering propositions on variable relationships and outcome predictions (linking social capabilities and shared TBL value creation). By highlighting the social capabilities of social entrepreneurs, this research illuminates the micro-foundations of Corporate Social Responsibility (CSR), emphasizing the value of individual level analyses.
\end{abstract}

Keywords: Natural Resource-based View, Resource-based View, Shared Value, Sustainability, Triple Bottom Line, Social Business, Social Entrepreneurship 


\section{INTRODUCTION}

Today, "sustainable business" still represents an economically-focused perspective which employs varying degrees of Corporate Social Responsibility (CSR) efforts such as energy efficiency, reduced carbon footprint, recycling and reuse, fair employee treatment, and charitable giving (Fallon 2014). Businesses taking this perspective have addressed only a small portion of the global sustainability challenges, which have grown in proportion. Environmentally, for example, the current worldwide resource footprint requires approximately 1.5 planets to sustain existing life, and by 2030 closer to two planets will be needed to sustain consumption (Moore et al. 2012). In 2016, actual worldwide consumption surpassed the budgeted resources by August $8^{\text {th }}$ (Global Footprint Network 2016). Socially, about 900 million people in the developing world live at or below US $\$ 1.90$ per day (World Bank 2015) and have restricted access to rapidly diminishing natural resources.

These current challenges highlight that instead of embracing a new paradigm in which environmental and social concerns may come first (Montabon et al. 2016), corporations are still highly influenced and rewarded by the popular notion that the business of business is business; in other words creating profit for shareholders (Friedman 1970). On the one hand, the increasing coverage of CSR topics in annual reports suggests an awareness of additional stakeholders' concerns related to social and environmental issues (Tate et al. 2010). On the other, in practice organizations are still challenged in responding holistically to the call from stakeholders (Matos and Silvestre 2013) to consider the firm as a coalition of suppliers of resources with the aim to increase collective wealth ${ }^{1}$ (Freeman and Reed 1983) in the system versus the independent wealth of a single firm.

\footnotetext{
${ }^{1}$ Collective wealth has evolved into concepts such as TBL sustainability (Triple Bottom Line; economic, environmental and social; Elkington, 1998) and shared value (Porter and Kramer, 2006, 2011).
} 
In line with practice, business research has predominantly focused on how companies achieve economic performance or sustained competitive advantage by deploying specific capabilities (e.g. Barney 1991; Teece et al. 1997; Teece 2007; Wernerfelt 1984). However, the capabilities needed to address ecological and, particularly, social issues are comparatively unexplored (e.g. Norman and MacDonald 2004; Hart and Milstein 2003). While the Resourcebased View (RBV) brought to research and practice the terminology and framework needed to understand how companies derive economic sustained competitive advantage from resources and capabilities, and Natural Resource-based View (NRBV) addressed these resources and capabilities on the environmental outcome side, neither focused on social capabilities or triple bottom line (TBL) sustainability.

There are some organizations, often entrepreneurial start-ups or small businesses ${ }^{2}$, that pursue impacts that address these stakeholder issues holistically (Lyons 2013). Social entrepreneurs look at TBL impact to stakeholders on both the demand and supply side of the business model (Thake and Zadek 1997). Social business models create value by addressing economic, environmental, and social elements, by promoting equitable relationships among stakeholders, and by adopting a fair revenue model (Boons and Luedeke-Freund 2013). Such innovative social business models aim to address holistically all three sets of constraints economic, social, and environmental - of the context in which they are operating, especially when in developing countries or catastrophe-stricken countries (Yunus et al. 2010). These contexts often include issues of resource scarcity, absence of intermediaries, weak regulatory systems, and contract-enforcing mechanisms (Khanna and Yafeh 2005) and have greater transaction costs (Hahn and Gold 2014). This makes social businesses particularly interesting when viewed as laboratories that can help identify capabilities needed to manage a broad and

\footnotetext{
${ }^{2}$ Social business models can be adopted by firms of various sizes and start-ups (e.g. Pura Vida Coffee; Wilson and Post, 2013) or existing firms (e.g. the Grameen Danone collaboration; Yunus et al., 2010).
} 
diverse range of stakeholder interests and the resources and capabilities needed to achieve TBL sustainability.

There are many stakeholders of organizations who live at the Bottom of the Pyramid (BoP) (London and Hart 2011). BoP represents the majority of the human population (more than 4 billion people) with a yearly per capita income of about US $\$ 3,000$ or less, and live in areas that are often constrained economically, environmentally and socially (London and Hart 2011; Jones Christensen et al. 2015). The sustainability challenges of these communities include poor nutrition, lack of public sanitation facilities, limited access to basic health services, and limited education and work (Calton et al. 2013).

This constraints perspective is analogous to the theoretical roots of the NRBV of the firm (Hart 1995; Hart and Dowell 2010), which started out with the notion that "[i]n the future, it appears inevitable that businesses (markets) will be constrained by and dependent upon ecosystems (nature) [...]" (Hart 1995, p. 991). The same logic can be extended to recognize social constraints, which are particularly prominent in BoP contexts. Hart and Dowell (2010), in a review of NRBV fifteen years after its introduction, even raised the question: "Do our existing theories adequately address how firms can succeed in the BoP, or do we need to augment or even replace these theories?" (Hart and Dowell 2010, p. 1476). While RBV has evolved into a rather mature theory and there has been some reflection regarding the intersection of RBV and sustainability, Barney et al. (2011, p. 1310) suggest that contexts such as the $\mathrm{BoP}$ offer an "intriguing and fertile ground [...yet] theory development in this realm has been minimal".

In order to address such theory development, social businesses offer an opportunity to explore the capabilities needed to complement those that have been discovered in RBV and NRBV. The overarching purpose of this research is to understand what a Social Resourcebased View (SRBV) means and how social capabilities can complement these two perspectives 
and bridge a gap in both research and practice, linking together all three legs of the TBL: economic, environmental and social. Thus, this paper seeks to make first strides toward an organizational level theory of SRBV as an elaboration of RBV.

Clarifying what is regarded as "theory" in this research, the article by Wacker (1998) is followed by structuring the discussion around the four main components of theory: 1) definitions of terms or variables; 2) a domain where the theory applies; 3) a set of relationships of variables; and 4) specific predictions (factual claims). In this research, the theory forming the basis is the RBV, which has already been extended by the NRBV, and its components are modified toward an SRBV. The first research question relates to the first theory component (variables), and the second extends the scope to components two, three and four (the domain, relationships and predictions). The specific research questions are: 1 . What capabilities are part of an SRBV? 2. How can an SRBV be conceptualized?

The research questions are addressed by first revisiting the literature on RBV and NRBV to understand the theoretical components from these two views. Literature and illustrative cases regarding the capabilities of social entrepreneurs running TBL sustainable businesses are then analyzed systematically. These analyses provide a comprehensive assessment of complementary social capabilities (SRBV), as social business entrepreneurs employ a diverse range of resources and capabilities to achieve TBL sustainability. The paper concludes with a conceptual framework and propositions for an SRBV.

\section{THEORETICAL BACKGROUND}

The relevant literature is reviewed in terms of the four components of a theory mentioned above (Wacker 1998); 1) definitions of terms or variables, 2) domain where the theory applies, 3) a set of relationships of variables and 4) specific predictions (factual claims). The literature helps position the SRBV as an elaboration of RBV. 


\section{Variables, Domain, Relationships and Prediction: Capabilities in the RBV}

There are a number of theories regarding how acquisition and deployment of resources and capabilities enable firms to compete, including the RBV (Barney 1991; Wernerfelt 1984), Resource Advantage (Hunt and Morgan 1995) and Dynamic Capabilities (Eisenhardt and Martin 2000; Teece et al. 1997; Teece 2007). The common theme across these theories is that an advantage can be gained by firms that develop distinct capabilities and can leverage resources that are rare, valuable, inimitable/substitution-resistant, organizationally specific, and heterogeneously distributed. Therefore, in terms of variables, RBV offered resources and capabilities.

As Hart summarized (1995, p. 988f.): “[ ...] resources are the basic units of analysis and include physical and financial assets as well as employees' skills and organizational (social) processes. A firm's capabilities result from bundles of resources brought to bear on particular value-added tasks (e.g. design for manufacturing, just-in-time production)." This helps define specific terminology which focuses on capabilities and the basic assumption that bundles of resources underlie these capabilities. Specific capabilities put forward in RBV have been, for example, R\&D and technological capabilites (e.g. Peteraf 1993; Wernerfelt 1984; Prahalad and Hamel 1990).

For domain, RBV assumes a competitive market situation in which firms as entities compete against each other on commercial terms (e.g. Chatain 2011; Peteraf 1993). The value creation is seen as rents created at the focal firm, and the firm achieving sustained competitive advantage (e.g. Peteraf 1993). This commercial focus emphasizes certain stakeholders, such as customers, investors, and competitors.

In terms of relationships, RBV puts forward the idea that companies utilize and develop capabilities and resources with the goal of achieving sustained competitive advantage. To establish an NRBV, Hart (1995, p. 988) summarized the RBV as the baseline. To facilitate 
theory elaboration and development of an SRBV, the theory components are incorporated in Hart's original depiction in Figure 1. This is used as the baseline for theoretical elaboration.

[Please insert Figure 1 about here]

\section{Variables, relationships, and prediction: Capabilities in the NRBV}

The NRBV variables extend the capabilities in scope toward those that are necessary to manage environmental constraints. NRBV changed the scope of the domain to include the constraints of the natural environment, extending the scope of what the firm considers as its context. Practitioners and academics understand the importance, complexity, and challenges of managing the natural environment when population and economic growth are considerable, consumption of fossil fuels is on the rise, and global industrial production continues to increase (Tate et al. 2010). NRBV as a theoretical extension thus has a wider domain of application than the original RBV and has addressed the call to bridge the disassociation between humankind (and its economic organizations) and the natural world (Gladwin et al. 1995).

In terms of relationships between variables, while NRBV evolved from RBV, it focuses specifically on the relationships among firms' resources and capabilities to achieve competitive advantage within the context and constraints of the natural environment (Hart 1995). Thus, NRBV centers on how companies develop capabilities to also achieve environmental goals and originally included pollution prevention, product stewardship, and sustainable development (Hart 1995). The original conceptual framework of NRBV is shown in Table 1.

[Please insert Table 1 about here]

These original NRBV capabilities were ultimately complemented by differentiating sustainable development into clean technology and BoP, rephrasing the environmental portion as societal driving forces (Hart and Dowell 2010). While this was stated within the boundaries of NRBV, it can be seen as a first implicit move toward inclusion of the social side of TBL. The overall components of NRBV are summarized in Figure 2. 
[Please insert Figure 2 about here]

NRBV extended the domain to include the natural environment but it did not change the ultimate measure of performance of achieving (economic) competitive advantage. This can be interpreted as a reflection of an underlying instrumental logic; economic success is the ultimate goal, environmental might be a means to reach it, e.g. when energy costs can be reduced. This is in contrast to the recently proposed ecologically dominant logic (Montabon et al. 2016), in which the order to assess intended corporate strategies and actions is first environmental, then social and then economic viability.

\section{Variables, Domain, Relationships and Prediction: Identifying Social Capabilities in Social Enterprises, Hybrids, and Cross-Sector Partnerships Literatures}

What are social and hybrid businesses?

When discussing social resources, some specific terminology should be mentioned. First, hybrid businesses have combined economic and social goals but the combination must be economically viable (Battilana and Lee 2014). ${ }^{3}$ Next, social businesses are a hybrid organizational form ${ }^{4}$ with structures and practices adopted from other types of organizations (Doherty et al. 2014). Social entrepreneurs tend to develop hybrid organizations that are not about "making a profit" but about "making a difference" in the face of extreme challenges (Zahra et al. 2009). Therefore, social enterprises often are developed to tackle significant social problems such as access to health care, unemployment, and poverty (Jenkins and Fries 2012).

\footnotetext{
${ }^{3}$ While many hybrid businesses in the literature have a focus on economic and social goals (e.g. Santos 2012; Doherty et al. 2014; Gupta et al. 2015), but do not necessarily cover the environmental side, our sample within this paper features businesses with TBL sustainability objectives.

${ }^{4}$ An organizational form is an "archetypal configuration of structures and practices" that is "regarded as appropriate within an institutional context" (Greenwood and Suddaby 2006, p. 30).
} 
Toward a broader domain: Stakeholders in CSR, BoP, and hybrid organization literatures

As social constraints are brought into focus, there is a need to broaden the scope beyond what the NRBV has done in terms of incorporating the natural environment, to further include a broad stakeholder base apart from customers, investors, competitors and others more closely linked to the economic success of a firm (RBV). For that purpose, the social enterprises, hybrids and cross-sector partnership literatures offer interesting insights, as they have a long tradition of looking at broad stakeholder bases, often with a focus on BoP or other challenging settings. Although it seems that many social enterprises are designed to give access to basic products and needs, social entrepreneurs, generally speaking, use innovative solutions to solve these more challenging problems (Gawell 2013; Rotheroe and Miller 2008).

One focus of the social entrepreneur is to try to improve the situation of the community in which the challenge resides (Yunus et al. 2010). These businesses strive to be innovative, are extremely in tune with their particular context, proactively manage and mitigate risk, all while being responsive and constrained by the need for economic viability (Weerawardena and Mort 2006).

Toward social capabilities: Capabilities in CSR, BoP, and hybrid organizations

Scholars have studied firms' social concerns for many decades (e.g. Berle 1931; Dodd 1932; Bowen 1953; Davis 1960; Frederick 1960). Although interest in CSR has become more widespread (Serenko and Bontis 2009; Wagner et al. 2009; Barnea and Rubin 2010; Jo and Maretno 2011) there is limited discussion on the individual level resources and distinctive capabilities required to successfully execute CSR (Aguinis and Glavas 2012). CSR “is contextspecific organizational actions and policies that take into account stakeholders' expectations and the triple bottom line of economic, social, and environmental performance" (Aguinis 2011, p. 855). It is also worth noting that there are multiple levels of analysis, as "the definition of 
CSR refers to policies and actions by organizations, such policies are influenced and implemented by actors at all levels of analysis (e.g. institutional, organizational, and individual)" (Aguinis and Glavas 2012, p. 933). A comprehensive review of the CSR literature concluded that the individual level of analysis is the least studied, but holds particular potential to better understand the micro-level foundations of CSR (Aguinis and Glavas 2012). By focusing on entrepreneurs' capabilities, this study addresses this research gap.

Turning to concrete capabilities in the social business setting, the literature on CSR, BoP, and hybrid organizations is revisited to take what has been (often implicitly) discussed in order to explicitly address social capabilities. For the purpose of an SRBV, a social capability is defined ${ }^{5}$ as the capability to leverage internal and/or external stakeholder relationships with the goal of reciprocal exchange. The exchange can concern information, products, labor force, and/or financial means, but also more intangible elements such as compassion, education, and care. The way to combine these capabilities requires solving tradeoffs, which may require additional altruistic rather than purely economic motives.

The literature suggests that there are conflicts in motivation (Jenkins and Fries 2012), many tensions between customer and beneficiaries of the organization, financing options that require multiple avenues of focus and also tax issues and other fiduciary responsibilities (Battilana et al. 2012). Therefore, social entrepreneurs must be able to span the boundaries of the private, public, and non-profit sectors (Tracey et al. 2011) and be able to reconcile conflicting institutional goals, structures, and processes (Pache and Santos 2012).

The flow of funds can be particularly challenging as businesses try to address multiple goals (Yunus et al. 2010). The entrepreneur must employ approaches that help meet revenue

\footnotetext{
${ }^{5}$ The term "social capability" also exists in economics to describe countries' overall education and technical competence, and the various institutions that shape the economic environment (e.g. Abramowitz 1986). That is not what is meant here.
} 
targets while seeking other sources of funding such as grants (Gupta et al., 2015), highlighting the role of financial institutions or partners. There can be a high risk for the entrepreneur of not being able to pay back the funds that are borrowed if the social business models are not well thought out and executed (Lepoutre and Aimé 2006), and hybridity can both help and hinder access to financial resources. Hybrid organizations can suffer disadvantages in terms of loss of legitimacy (Brandsen and Karré 2011; Minkoff 2002), reducing access to resources (D'Aunno et al. 1991) and increasing organizational mortality (Barron et al. 1994). Thus, they need capabilities in reporting to multiple stakeholder groups with multiple conflicting priorities, as well as transparency of data.

Regulatory issues, corruption, and bureaucracy are also challenges faced when executing business models in some of the more challenging regions of the world (BCTA 2011). Capabilities are needed regarding the monitoring and measuring of impact, and the ability to define metrics and measures that drive the appropriate behavior is key (Haugh 2005), although there is significant debate regarding the appropriate economic, environmental and social metrics and measures (Haugh 2005; Searcy 2012; Lisi 2016; Hussain et al. 2016; Longoni and Cagliano 2016).

Many conflicts regarding mission, financial resource acquisition and human resource mobilization need to be overcome in hybrid businesses (Gupta et al. 2015). Access to the customers at the time when they need the products and have the ability to afford the products requires additional means for delivery. Many initiatives to address these more social needs take a long time to scale, especially when infrastructures are challenging. For example, the business would most likely fail unless local social partners are brought into the business during market creation and the product development/distribution phase (Calton et al. 2013), so identifying these local social partners is a key capability for a social entrepreneur. 
Collaboration with others can help with technical issues, governance and management of multiple stakeholders, and in other areas such as process and quality issues (e.g. Selsky and Parker 2005). This is particularly crucial where there is a lack of trust and a weak government, in addition to issues related to poverty, human rights violations, and environmental degradation (Brück et al. 2011; Naude et al. 2011). Shared experiences and information exchange are vitally important, and the entrepreneur must identify key collaborators from many different types of stakeholders - public, private, hybrids and community (Kolk and Lenfant 2015). Being able to identify third parties for financial resources, whose interests fit the enterprise's mission, and to maximize that alignment is critical (Dees 1998).

Also related to stakeholder relationships, stakeholder management capability has been positively associated with the adoption of proactive CSR (Torugsa et al. 2012). Even in the revisit of $\mathrm{NRBV}$, one stakeholder management capability mentioned is being able to understand the societies that exist at the BoP (Hart and Dowell 2010). Normann and Ramirez (1993) suggested that value in a business network results from a value creating system including suppliers, customers, and other stakeholders that has these actors co-producing value instead of forming a sequential chain. This makes the reconfiguration of relationships and roles in this constellation of actors a key task (Normann and Ramirez 1993).

Turning to suppliers as one stakeholder group, it is possible to identify an emergent evolution toward an SRBV in the supply chain management literature. Two environmentaloriented supply chain capabilities, collaboration and monitoring, (Klassen and Vachon 2003) were more recently complemented by (social) innovation to achieve positive social outcomes, and put forward as "three key social management capabilities [emphasis added]" (Klassen and Vereecke 2012, p. 103). This is yet another example of why the terminology and theoretical lens of an SRBV will help harmonize and advance research. 
Table 2 summarizes the primary social capabilities from these streams of literature. These capabilities currently come under various headlines, such as social issues, resources, and capabilities, providing another reason SRBV might act as a unifying theoretical basis. In line with the social capability definition used above, that reciprocal exchange in relationships lies at their core; the capabilities are ordered from more internally to more externally oriented. So while ethical and social commitments and the mission-driven approach very much lie within the business, the external scope increases to capabilities such as how to achieve supply/value chain collaboration or how to manage various other external stakeholders.

[Please insert Table 2 about here]

Revisiting the variable relationships in CSR, BoP and hybrid organizations literatures

Turning toward relationships of variables, the social entrepreneurship literature investigates how different types of entrepreneurs garner and deploy different types of capabilities and resources ${ }^{6}$ in pursuing their respective opportunities (Zahra et al. 2009; Corner and $\mathrm{Wu}$ 2012). In a similar fashion, Mair and Marti (2006) see social entrepreneurship as a process which creates value by combining resources in new ways and which is primarily intended to explore and exploit opportunities that create social value through the stimulation of social change or meeting social needs. One significant capability is that, during the design of their social model, the entrepreneurs are able to make use of their personal, idiosyncratic resources such as skills, knowledge and relationships (Corner and Ho 2010).

Social entrepreneurship literature has been adopting the idea that there are economic, environmental and social resources that are utilized simultaneously by entrepreneurs (Murphy

\footnotetext{
${ }^{6}$ Although the social entrepreneurship literature more often utilizes the wording "resources" instead of "capabilities", we see this nevertheless in the spirit of an SRBV; due to the disparate terminology existing in the literature, these studies might only partly refer to resources and/or capabilities as defined earlier in this paper.
} 
and Coombes, 2009). One model particularly aligned to the idea of an SRBV is the 3C-SR (Commitments, Connections, Consistency-Social Resources) model by Meehan et al. (2006). In this model, social resources are made up of three inter-related components whose simultaneous presence underwrites the credibility of a product/service offer targeted at the "ethical consumer" that needs to be cultivated - ethical and social commitments; connections with partners in the value network; and consistency of behavior over time - to build trust. They see certain capabilities, i.e. supply-chain expertise, collaborative capability and R\&D capability, as supportive for that cultivation. Regarding consistency, the main argument is that this entails the behavioral element of social resources over time and across all areas of an organization's operation, and that the negative version of this corresponds to the scenario that CSR fails when companies do not walk their talk (Meehan et al. 2006).

\section{Toward TBL outcome prediction: Shared TBL value}

Turning to the prediction of outcomes in an SRBV, corporate performance should cover economic, environmental, and social objectives (Bowen 1953; Carroll 1979, 1999). Whereas RBV centers on classic economic performance indicators such as market share and rents (e.g. Barney 1991; Mahoney and Pandian 1992; Peteraf 1993), in order to operationalize TBL sustainability outcomes, all three dimensions have to be managed to deliver general stakeholder and local community value; the latter coming back to the notion of collective wealth (Freeman and Reed 1983).

The outcome prediction in an SRBV is termed "shared TBL value" as the ultimate measure of TBL sustainability. Porter and Kramer (2006; 2011, p. 64) defined shared value as a principle "[...] which involves creating economic value in a way that also creates value for society by addressing its needs and challenges. Businesses must reconnect company success with social progress. Shared value is not social responsibility, philanthropy, or even 
sustainability, but a new way to achieve economic success. It is not on the margin of what companies do, but at the center [...]" and aims at an increase of overall value creation, not just mere redistribution. Though not emphasized, Porter and Kramer covered all three TBL dimensions; for example, "less environmental damage" (2011, p. 67) was captured as a societal need. Therefore, "shared TBL value" addresses all TBL dimensions, while keeping in mind the perspective of connecting the generation of value in all TBL areas (Kleindorfer et al. 2005) for a broad base of stakeholders with economic, social and environmental stakes.

Shared value has been criticized in the literature (e.g. Crane et al. 2014) and is in a rather nascent stage (Dembek et al. 2015). Still, there is a need to "provide shared value with meaning and organizations with guidance how to implement it" (Dembek et al. 2015, p. 15). This research puts forward "shared TBL value" to operationalize TBL sustainability with such a broad stakeholder and clear TBL scope.

\section{METHODOLOGY}

\section{Research Design}

Existing theory has not incorporated all three legs of the TBL - there currently is no SRBV that would address the social dimension. Therefore, this research takes a theory elaboration approach. It builds on the theoretical framework of RBV (and its extension NRBV) and elaborates and enhances it with illustrative empirical data, along the four components of theory: Variables, domain, relationships between variables and predictions (Wacker, 1998). As presented in the introduction, the specific research questions are: 1. What capabilities are part of an SRBV? 2. How can an SRBV be conceptualized?

Case study research was chosen as the methodology, particularly to understand the how aspects of the research questions (Yin, 2009; Ellram, 1996). Different to theory testing or development, the theory elaboration approach in case study research is suitable when 
conceptual ideas exist that can provide a foundation for the empirical research, but it is lacking tenets that are not yet sufficiently detailed to formulate hypotheses for testing (Ketokivi and Choi 2014; Lee et al. 1999). Based on abductive reasoning, theory elaboration emphasizes the interplay between empirical data and theory (Dubois and Gibbert 2010). Data serves to illustrate and elaborate (Ketokivi and Choi 2014). In this research, RBV (and NRBV) provide the overall theoretical framework that is used as the basis of the empirical study and then evolves into a more detailed framework with the empirical analysis (Dubois and Gibbert 2010). What results are the elaboration of variables, the domain, variable relationships and outcome predictions of an SRBV. Empirically, cases of social businesses in Haiti are used to help illustrate capabilities used to deliver shared TBL value.

\section{Sampling, Data Collection, and Analysis}

Research on larger firms shows a sequential multiple step approach of integrating TBL concerns, with the ultimate goal of improving TBL sustainability. Porter and Kramer (2006) described how many companies responded only after being surprised by public responses to issues that they previously ignored as their responsibility, such as Shell's Brent Spar decision (sinking an obsolete oil rig) or Nike and the reports on its abusive labor practices in Indonesia in the early 1990s, and then responded cosmetically (e.g. with public relations and media campaigns). These responses were largely in the form of public statements of CSR (Porter and Kramer 2006). Instead, social businesses are mission-driven businesses with TBL outcomes designed in at conception, permitting a look into a laboratory of sustainable and innovative business models. For the elaboration of RBV toward an SRBV, the intent was to identify businesses that aim at positive outcomes on all three TBL sustainability dimensions and also operate in a highly constrained context where economic, environmental and social issues pressure the distinct capabilities that are necessary to succeed. 
Yunus Social Business (YSB) was approached for purposes of data collection. YSB is an umbrella organization for social business ventures and also acts as an investor. YSB was co-founded by Muhammad Yunus, a 2006 Nobel Peace Prize winner (see Appendix A). The financial resources to be invested in the individual social businesses come from donations or as philanthropic loans, which are ultimately paid back. The YSB headquarters in Germany was contacted to help select the appropriate country and the respective social businesses to be studied in detail. The country selection followed a sampling criterion in which the businesses had been established for more than two years to allow the researchers to follow their trajectory. Also, the specific location needed serious constraints in order to observe the capabilities utilized to overcome these and achieve the intended and necessary TBL outcomes.

This led to the selection of catastrophe-ridden Haiti, one of the countries where YSB has its longest presence, and offered a setting with serious challenges in all three sustainability dimensions. Social entrepreneurs have a catalyst role in promoting social welfare, something that resonated well with the TBL shared value concept. For the specific social business selection, YSB sent their complete portfolio of running and perspective social businesses to the research team and noted that it has three different business model types.

The profiles were analyzed for coverage of the three sustainability dimensions and the different business models. The tentative case selections were then discussed with the Haiti Country Manager at YSB to determine which cases from the Haiti portfolio would fulfill the requirements. This led to the selection of the social businesses EPRO, CHIFA, and CLEAPRO (all anonymous names).

EPRO is a social business offering cooking and lighting products, such as cooking stoves and solar lamps. CHIFA is a social business producing chicken meat as a means to generate funding for a school. CLEAPRO is a social business offering cleaning products such as detergents (cleansing agents that are effective for washing clothes and dishes), disinfectants 
(substances that are applied to non-living objects in order to destroy microorganisms that are living on these objects) and bleach (used to disinfect surfaces, remove stains, whiten clothes or also purify water for drinking).

After the initial sampling discussions with YSB headquarters, an interview was first conducted with the country and investment manager of the Haiti office in order to understand the overall YSB Haiti social business perspective, as well as to agree on the data collection procedure. The country manager was contacted and interviewed on multiple occasions, when discussing the selection of the businesses, for clarifications and also to hear her perspective (e.g. on the planned versus actual performance) of these three social businesses. Dedicated interviews with representatives from the three social businesses then were performed. An overview description and interviewees in each of the cases are shown in Table 3.

[Please insert Table 3 about here]

During data collection, two researchers were present to ensure clarity and understanding of the information being provided. While the data collection followed the interview guide, the final questions were more open-ended to allow for direct or follow-up questions. The interviews were recorded and transcribed for later analysis. For content validation, the interview summaries were sent to the interviewees and a full within-case assessment was provided as the data was compiled. A final cross-case analysis was also sent for approval. Each of the interviewees was contacted for additional information and clarification as the coding process continued.

Furthermore, additional sources of data such as business plans, profit and loss statements, YSB eligibility and investment criteria, investor summaries, and organizational charts were used to compare interviewee information with additional documentation (e.g. on the objectives pursued). These measures served to mitigate biases and enhance reliability and validity (Eisenhardt 1989; Jick 1979; Yin 2009). The additional sources of data comprised the 
full business plans of all studied social businesses (both text and calculations), the YSB eligibility and investment criteria, and the investor summaries of all social businesses (these are standardized documents required by the headquarters in Germany and include economic, social and environmental objectives, (financial) investment required, context, business model, and social impact ${ }^{7}$ ). There was also data gathered through Internet searches related to the social businesses.

All of the case input was coded based on the literature review (RBV, NRBV, 3C-SR model etc.) plus open coding. Particular focus was on which capabilities they display (the main variables (theory component 1 ), how broadly they define their stakeholders (the domain, theory component 2) to achieve their TBL objectives (relationships between the variables, theory component 3), and factual claims (theory component 4).

\section{CASE RESULTS}

\section{Insights from the Cases Regarding the Variables (Component 1): Capabilities}

The various capabilities identified from the case data can be seen in Table 4. All three social businesses feature capabilities from the perspectives of RBV, NRBV, and SRBV. The way of displaying the identified capabilities in this cross-case analysis follows previously published comparison tables (e.g. Pagell and Wu 2009).

\section{[Please insert Table 4 about here]}

It is notable that these three social businesses cover all three legs of the TBL. The economic and environmental capabilities are rather homogeneous across the firms. All possess economic top line revenue management, production innovation capabilities (here with a focus

\footnotetext{
${ }^{7}$ Despite the name this will feature economic, environmental, social impact, depending on the respective business model. The cases CHIFA, EPRO and CLEAPRO covered all three impact dimensions.
} 
on affordable products) and distribution capabilities in line with the local context, and the environmental capabilities of pollution prevention and environmental impact.

With respect to social capabilities, a number of these discovered in the literature were reflected in the cases. The businesses are built around specific missions. In each of the three cases the respective interviewee highlighted the primary idea of using the social business to improve the local situation. Two constructs that were most pronounced in the coding were the mission-driven approach and stakeholder management. Table 5 highlights how these two constructs were mentioned in the cases.

[Please insert Table 5 about here]

An example of how the mission is pursued over time is how some of the interviewees explained the issue of "free versus affordable products". The entrepreneurs actually saw the notion of "free", meaning products backed up by donations, as detrimental to sustainability goals. For example, interviewee B explained that after a catastrophe an NGO had given out 5,000 free stoves and with that had basically "killed the business" of many retailers, meaning that although some people got a stove for free, all others that were interested would not be able to find a market to buy one in the future as that market died off. As the Haiti office manager (Interviewee A) mentioned on this phenomenon: "Anything that is free has no value [...] Poorest people are the smartest [...] they buy under so many constraints." In order to pursue their mission over time, they identify those organizations that might help negate these generous, but not value-adding, donations. In the mentioned example, EPRO got in touch with the NGO and successfully convinced it to charge a small fee for the product to give it some "value".

In all three cases specific objectives and metrics were defined in the business plans to track performance, in order to ensure that they keep on track with their mission. All three present innovative ways to advance their missions: EPRO by making its products affordable via a micro-credit partner, CLEAPRO by eliminating its packaging and CHIFA by creating a 
business to fund local schools. To bring their models to life, these companies, from inception, designed certain collaboration partners into their models. For example, EPRO designed the participant ID microfinance into their value chain early on so that micro-credits are directly available for purchasing their social products. An example of supply/value chain cooperation for products is CLEAPRO's identification of a suitable point of sale (POS), i.e. gas stations and small entrepreneurs, as an integral part of their model, and particularly critical to product delivery given the country's infrastructure. All three integrated such stakeholders from the start and also actively engage in work with NGOs and ministries. Lessons from the social entrepreneurs indicated that leveraging these stakeholder inputs was central to the success of the three businesses in lowering the barriers to conceive and execute their businesses.

Stakeholder integration becomes most localized in CHIFA's case, in which local community involvement was part of the model from the start; parents of school children and local neighbors of the farm are directly involved (e.g. to help with repairs, if necessary). As interviewee $\mathrm{C}$ at CHIFA explained: "[...] talked to the community, invited them to come to the farm to buy chicken, sell them the vision, the social business vision" and now that it is running "it is the community who works on the building, the construction [...and] next week we're going to have an open house, we're planning to have an open house, and the open house is going to let them come inside and see what's going on inside of the business, the farm”.

Four areas of stakeholder contribution were differentiated based on the coding of cases and are summarized in Table 6. These four areas include funding (the provision of financial resources, mainly in the form of equity share or credits); expertise (such as business development input or technical consulting); products (such as the provision with finished products or production inputs, mainly referring to suppliers of the businesses); and context shaping (for example by ministries which shape the business environment). The latter has also been identified as a capability of firms aiming for TBL sustainability (Glavas and Mish 2015). 
[Please insert Table 6 about here]

\section{Insights from the Cases Regarding the Domain (Component 2): Pursuing Embeddedness in the Local Context}

It is noteworthy that in all three cases the business models are developed with a clear understanding of the local environment and stakeholder community. The capability to understand what drives stakeholder value and to harness the energy around the stakeholders was eminent in the cases. As interviewee $\mathrm{C}$ at CHIFA put it "Well, I think we have the will to get it done, and we have a community that is in need so they understand that what you're doing is important [...] The community knows that the business belongs to them ${ }^{8}[\ldots]$ ".

The previous section highlighted which stakeholders were involved in strategy inputs. It now is important to address the objectives of the firms in terms of for whom they wanted to create shared TBL value. A variety of stakeholders are involved, including those who are economically-oriented (e.g. financial institutions that have lent money or have micro-credit customers), socially-oriented (e.g. the teachers and parents of school children, poor women who are food vendors and families who need hygienic cleaning solution), and environmentallyoriented (e.g. the local ecosystem).

\section{Insights From the Cases Regarding the Variables Relationships and Factual claims (Components 3 and 4): Shared TBL Value}

The overview of the main objectives according to the companies' business plans and interviews are summarized in Table 7. All three cases target shared TBL value creation in their respective stakeholder networks, and at the time of the interviews all three were on track with these goals (according to both the interviewees from those businesses as well as the YSB coordinator who tracks the progress). These are also discussed in the paragraphs below.

[Please insert Table 7 about here]

\footnotetext{
${ }^{8}$ That expression is just meant figuratively; the local community does not have equity stakes in the business. What is meant it that they are the ones this business wants to create value for.
} 
The entrepreneurs represent and implement a strong desire to achieve shared TBL value for their broad network of stakeholders through their social business. Although financial goals are a central part of all three business plans, the main and future objectives reflect a TBL approach for setting up a sustainable business. Even in the case of CHIFA, where there is no explicit main objective in the environmental dimension, this aspect is part of its strategy formulation, as it seeks to avoid any chemical pollution and also sells chicken waste as fertilizer. As interviewee $\mathrm{C}$ at CHIFA explained

"For instance, to be environmentally conscious as an organization, as a social business, we have to deal, to collaborate, with organizations that work with the environment and agriculture. For instance, the waste of the chicken, we have to take it to other organizations in the community that do agroecology or agriculture."

All of these objectives are specified with clear indicators, targets, measuring tools and terms (Table 7). For example, the objective of "improving the quality of education within four schools" has an indicator of "academic achievement at the end of year examinations". The specific target is an improvement by $20 \%$, and the measurement tool is school performance on monthly, quarterly, and centrally coordinated examinations of performance results.

Coming back to the two key capabilities identified in the cases - a mission-based approach and stakeholder management - the business plan metrics highlight how they are able to translate their mission into measureable and reportable metrics that can be utilized for steering the business. In terms of stakeholder management, they utilized the expertise of YSB as one of their key stakeholders. When prompted to summarize their impacts, they did not see an issue with achieving either one or more of the TBL objectives. As interviewee D at CLEAPRO stated:

"In terms of environmental, people use less plastic bottles by buying our product this way, so less trash in the street. Social impact, people have access to cleaning products 
that improve their environment and their lives. Economic impact, all of our point of sales take 30\% profit on what they sell, so [...] I think in a way, all these 3 things are very achievable and have been achieved so far."

When considering what enabled the three social businesses to actually reach their objectives, we can see from the cases that all of them had capabilities from all three views RBV, NRBV and SRBV. This research has not tested that relationship. Instead a related proposition will be offered in the next section as part of an emergent SRBV for further testing.

\section{TOWARD AN SRBV: VARIABLES, DOMAIN, VARIABLE RELATIONSHIPS AND PREDICTIONS}

Figure 3 below summarizes the emergent components of an SRBV, together with RBV and NRBV. The respective propositions are referred to in this figure as well and are discussed in the paragraphs below.

[Please insert Figure 3 about here]It is particularly noteworthy that, apart from elaborating on additional variables and their relationships, this conceptual framework also includes an elaboration of the domain (component 2) and outcome prediction (component 4). Both of the latter are deemed crucial in developing a theoretical framework that bridges the instrumental logic of economic performance of a particular focal firm (and its holders of economic stakes in RBV, extended by holders of environmental stakes in NRBV), and the concept of shared TBL value of a firm in and for its broader stakeholder context.

\section{Theoretical Implications}

In the spirit of Hart's 1995 proposal of an NRBV, Table 8 summarizes the main findings of the cases in that way as a conceptual framework. While these two strategic capabilities were the two most prominent in our case data, the limitations are acknowledged and suggest that 
future research should be open to many other potential social capabilities (such as identified in Tables 2 and 9, or to be newly identified).

[Please insert Table 8 about here]

Continuing with the variables (component 1), what is proposed is structuring the social capabilities according to the earlier mentioned 3C-SR model (Meehan et al. 2006). Notably, upon reflection of the two most pronounced capabilities in the cases, the mission-driven approach (at inception) is regarded as a sign of commitment, and pursuing this mission-driven approach (over time) as consistency. The second most pronounced capability, stakeholder management, corresponds to connections. Therefore, the social capabilities identified are arranged according to these three areas in Table 9.

[Please insert Table 9 about here]

Concluding on the variables, an SRBV is suggested to feature capabilities that center on how companies can achieve their mission in the context of a broad stakeholder network. Not making a relationship to any outcome prediction relationships (component 4), this leads to the following basic proposition:

Proposition 1: An SRBV includes social capabilities in the three areas - commitments, connections and consistency.

In terms of testability, this first proposition is more about exploring variables in the future and identifying whether the three areas proposed are truly exhaustive or have to be expanded and/or reduced. Also, further work on operationalization of the constructs for future testing is needed.

Continuing with the domain (component 2), the scope of the business stakeholders for whom to create value in the cases was indeed very broad, including a detailed understanding of the local community besides the rather generic stakeholder categories such as customers and suppliers. The entrepreneurs extended the scope to include competitors, not for profit organizations and other investors, and also considered the natural environment. This is also in 
line with a recent study on TBL sustainable firms that found that in contrast to the approach of a firm within RBV, companies with a TBL sustainability scope draw no strict boundary between the firm and environment, but integrating the firm into the external context of society and environment (Glavas and Mish, 2015). Thus, the following is proposed:

Proposition 2: An SRBV's domain includes a very broad stakeholder network, including economic, social and environmental stakeholders.

In terms of testability, this second proposition is about defining the realm to which an SRBV applies. For future research, this is mainly an aspect to take into account in research design. But how to operationalize it empirically and how to approach it methodologically may be broadened and refined as well.

With respect to the variable relationships and predicted outcomes (components 3 and 4) in the theoretical background it was proposed that (although TBL-oriented in its origin), the term "shared value" is extended to "shared TBL value" to highlight the three-dimensional focus for the outcome predicted. Indeed, the cases analyzed covered objectives in all three areas economic, environmental and social - and the entrepreneurs in these organizations showed social, economic, and environmental capabilities. Thus, we propose:

Proposition 3: Social capabilities are a prerequisite to create shared TBL value.

In terms of testability, this third proposition is the most general relationship proposition made here. More specifically, future research should investigate whether 1) without social capabilities, shared TBL value can or cannot be reached; and 2) whether it is necessary that capabilities from all three views (RBV, NRBV, SRBV) are present simultaneously to create shared TBL value.

As for the more specific social capability-outcome relationships, the clear missiondriven approach prevailed for the studied social businesses in order to create and maintain shared TBL value across the extended supply chain. The mission serves as a constant compass for decision-making. This compass guides all subsequent decision-making and prevents the 
model from eroding over time, which would mean gravitating toward an economic focus. Instead, even after conception the mission is what guides actions. Thus, we propose:

Proposition 3a: A mission-driven approach (at inception and over time) has a positive impact on shared TBL value creation.

In terms of testability, this is a very specific capability-outcome relationship. The only aspect to highlight here is the differentiation of the timing of the measurement. At the beginning of the social business formation, this variable would count as part of the aspect "commitment"; later in the process it would count under "consistency" (as was shown and explained in relation to Table 9).

As indicated in the literature review, the ability to configure the stakeholder network is a key capability for a social business. Also, all three cases highlighted the importance of consciously designing and managing the stakeholder network. These businesses regard the ability to embed themselves in the local context as a key contributor to success as the social business model is being designed, even before the business plan is developed. None of the participants shy away from building up relationships that either provide them with contacts to another supply chain member, such as in the case of EPRO and the micro-credit institution that adds another layer to its financial flows, or, as in the case of CHIFA, with regard to being completely intertwined with the local community school, both in financial terms and having the school's "customers" (the children's parents) being a major part of their customers. Interestingly, this network of value chain partners is not only built to create additional value within the chain, but also actually to prevent the destruction of value, as in the case of actively collaborating with an NGO to change its behavior from giving out free products and, as a result, destroying the market for social products such as stoves and solar lamps. Hence:

Proposition 3b: Designing and managing value chain partners with complementary capabilities into the business model has a positive impact on shared TBL value creation. 
In terms of testability, this is also a very specific capability-outcome relationship. Again, the timing of the measurement should be highlighted. For example, at the beginning, related to network design, this would correspond to the capability "Value Chain Partner Network Design”. When more related to management over time, this would correspond to the capabilities "(Supply/Value Chain) Collaboration in terms of suppliers and/or financial partners" and "(Supply Chain) Monitoring” (Table 9).

\section{Practical Implications}

The following practical insights can be put forward. First, as a managerial implication companies need to become aware that in order to achieve shared TBL value, social capabilities play a role as well. It has become commonly accepted that certain capabilities are needed to achieve (economic) competitive advantage, and increasingly that additional capabilities are needed to enhance environmental performance, but the need to consciously build up social capabilities to successfully create shared TBL value is a new insight to managerial practice. This may imply adaptations in hiring policies as well as training and development of employees. To identify and recruit talent that understands the concept of shared TBL value, the mission and the needs of the stakeholders become critical for success. Specific social capabilities that stand out in their importance within the empirical part presented here were "following a mission-driven approach" and "stakeholder management". These are therefore suggested as first practical starting points for human resource development.

Second, as the case studies highlighted the importance of starting from a TBL-oriented mission and maintaining it as a constant compass for decision-making, an expected challenge for managers will be to consider that these "mission-driven approaches" may run counter to other missions or goals. This implies that in order to foster shared TBL value creation, general strategic reorientation may be necessary. The ultimate benefit for the company itself, though, 
would be that the mission-driven approach, combined with consciously building up social capabilities, could help prevent CSR pitfalls and help CSR be truly value-enhancing.

Third, a practical implication for higher education would be to integrate the development of such capabilities more consciously into business curricula, be it in relation to fields such as entrepreneurship, business ethics, supply chain management, or general management. Again, the social capabilities "following a mission-driven approach" and "stakeholder management" are proposed as starting points for such efforts. Apart from inspiring the creation of more social businesses, this could further promote a workforce for larger and/or existing companies possessing the required capabilities for a sustainable future.

\section{CONCLUSIONS, LIMITATIONS AND FUTURE RESEARCH OPPORTUNITIES}

This research set out to address the issue that even after decades of efforts, the achievement of TBL sustainability still lags behind, and theoretical lenses in business research are still missing the social dimension. The research questions pursued were 1 . What capabilities are part of an SRBV? 2. How can an SRBV be conceptualized?

In terms of the first question, beyond the capabilities proposed by RBV and NRBV, social business entrepreneurs employ a broad range of capabilities, which include social capabilities. Based on both a literature review and the cases, a number of social capabilities are put forward here as an elaboration of the RBV toward an SRBV.

In terms of the second question, it was proposed that an SRBV extends the scope of the domain to include a broad range of economic, social and environmental stakeholders, and describes the relationships between social capabilities and achieving shared TBL value. If companies target shared TBL value creation, it is proposed that they need to possess the needed social capabilities and, actually, capabilities from all of the three views (RBV, NRBV, SRBV). This does not imply a separate paradigm that neglects the economic (corresponding to the 
RBV) or environmental aspects (corresponding to the NRBV). Instead, it was proposed that all three are part of an overall theoretical base for future research (Figure 3).

While this paper sought to mainly make a theoretical contribution by proposing an SRBV, the empirical context of the for-profit social entrepreneur is one that permitted a look into a laboratory of sustainable and innovative business models, thus allowing observation of the shared value concept in implementation by social entrepreneurs. This highlights a simple truth that ultimately, the capabilities mentioned will have to be possessed and applied by people. Following up on this thought could open up a new branch of research into social capability human resource management for corporations. Such a shift could also help further remedy the situation that CSR too often becomes a "company" issue rather than a people issue, preventing full commitment by the workforce (Juran 1995).

More recently, along the same lines, Aguinis and Glavas (2012) concluded, based on a comprehensive literature review, that the micro-foundations of CSR and multi-level (individual, organizational, institutional) predictor-moderator/mediator-outcome relationships need more research. By highlighting the role of social capabilities of entrepreneurs, this research sheds further light on the micro-foundations of CSR emphasizing the value of individual level analyses. It offers an SRBV as a theoretical lens to further study these aspects.

Establishing an SRBV in business research would turn the mentioned implicit evolution of an SRBV wording in social entrepreneurship (e.g. Torugsa et al. 2012) and Sustainable Supply Chain Management research (SSCM) (e.g. Klassen and Vachon 2003; Klassen and Vereecke 2012) into an explicit research agenda. It could help facilitate research in areas such as performance measurement and supplier relationship management in SSCM (e.g. Klassen and Vachon 2003; Seuring and Gold 2010; Klassen and Vereecke 2012; Hassini et al. 2012; Ahi and Searcy 2013). 
As for limitations, while the following must be acknowledged, they also open avenues for future research. First, selecting the cases from the investment network of YSB might have influenced the breadth and depth of the variables and their relationships, as YSB pre-selected them for their capabilities and to some degree facilitates their networking. For the purpose of analyzing cases that actually have a shared TBL value creation focus within a catastrophestricken geographic context that poses serious economic, environmental and social constraints, the sampling frame of these firms has been a great research opportunity to begin forming an SRBV. What is needed now, however, is research in other contexts - e.g. BoP and developed settings alike. Since this paper wanted foremost to make a first stride toward an SRBV, there remains ample opportunity to explore whether a wider variety of social capabilities than that identified in the literature and cases within this paper exist. Also, there remains ample opportunity to investigate whether some relationships are more important than others.

Regarding the outcome variables, this research suggested that shared TBL value is operationalized in environmental, economic and social terms for a broad stakeholder base (Figure 3), but did not focus on how these relate to each other. Should they be balanced or in some way prioritized? Future research could investigate this aspect by taking into account recent work on the anthropocentric versus ecocentric perspective (Borland et al. 2016) or the ecologically dominant logic mentioned earlier (Montabon et al. 2016). Also, questions arise whether these outcome variable relationships are similar for all organizations or may be different for stocklisted companies, B-Corps, social businesses and non-profits.

Methodologically, while the case study approach has facilitated the exploration of the four theoretical components of an SRBV with, first, empirical data, much remains to be explored and tested. The contributions based on that data are the conceptual frameworks and propositions shown in Table 8 and Figure 3. Testing the suggested propositions would be the next step. While the cases' very broad stakeholder focus came out both from the interviews 
and additional documents for extension of the domain, a further network analysis was not in the scope of this research. The further exploration of the aspect of embeddedness within the stakeholder network in relation to the theoretical domain warrants an interesting opportunity for future research. Additional qualitative research likely will be needed to further establish the variable constructs and their operationalization, before empirical testing of relationships via quantitative research methods can begin.

Finally, as mentioned in the introduction, Hart and Dowell (2010) asked whether in the face of BoP challenges we need to augment or replace theories, and Barney et al. (2011, p. 1310) suggested that contexts such as the BoP offer an "intriguing and fertile ground [...yet] theory development in this realm has been minimal". While the constraints in the natural environment had originally inspired Hart (1995) to develop the NRBV, the constraints faced in a context such as Haiti further inspired an SRBV.

This is an exciting and fruitful area of research. With a significant portion of the world's population still living in poverty, and with fundamental ecological challenges ahead, capabilities to overcome the barriers to achieve shared TBL value are needed in organizations great and small to effectively and efficiently foster overall sustainable development. While the RBV has helped research and practice to conceptualize the tenets of the economic success of firms, and its theoretical elaboration of an NRBV has added the environmental side, the addition of an SRBV offers an elaborated view that further extends the scope of future research and practice toward shared TBL value creation. 
Accepted version status October 2016; Journal of Business Ethics

\section{Compliance with Ethical Standards}

Funding: There is no specific funding to declare for this study.

\section{Ethical Approval}

All procedures performed in studies involving human participants were in accordance with the ethical standards of the institutional and/or national research committee and with the 1964 Helsinki declaration and its later amendments or comparable ethical standards.

Informed consent: Informed consent was obtained from all individual participants included in the study. 
Accepted version status October 2016; Journal of Business Ethics

\section{REFERENCES}

Abramovitz, M. (1986). Catching up, forging ahead, and falling behind. Journal of Economic History 46(2), 386-406.

Aguinis, H. (2011). Organizational responsibility: Doing good and doing well. In S. Zedeck (ed.), APA handbook of industrial and organizational psychology, 3, (pp. 855-879). American Psychological Association, Washington, DC.

Aguinis, H. and Glavas, A. (2012). What we know and don't know about corporate social responsibility: A review and research agenda 38(4), 932-968.

Ahi, P. and Searcy, C. (2013). A comparative literature analysis of definitions for green and sustainable supply chain management. Journal of Cleaner Production 52, 329-341.

Barnea, A. and Rubin, A. (2010). Corporate social responsibility as a conflict between shareholders. Journal of Business Ethics 97(1), 71-86.

Barney, J. (1991). Firm resources and sustained competitive advantage. Journal of Management 17(1), 99-120.

Barney, J., Ketchen, D. J. Jr. and Wright, M. (2011). The Future of Resource-Based Theory: Revitalization or Decline? Journal of Management 37(5), 1299-1315.

Barron, D. N., West, E. and Hannan, M. T. (1994). A time to grow and a time to die: Growth and mortality of credit unions in New York City, 1914-1990. American Journal of Sociology, $381-421$

Battilana, J. and Lee, M. (2014). Advancing Research on Hybrid Organizing-Insights from the Study of Social Enterprises. The Academy of Management Annals 8(1), 397-441.

Battilana, J., Lee, M., Walker, J. and Dorsey, C. (2012). In search of the hybrid ideal. Stanford Social Innovation Review 10, 51-55. 
Accepted version status October 2016; Journal of Business Ethics

BCTA (2011). Business call to action 2011. Barriers to inclusive business.

http://www.businesscalltoaction.org/wp-content/uploads/2011/03/Barriers-to-InclusiveBusiness-Final-LR.pdf. Accessed December 28, 2014.

Berle, A. A. (1931). Corporate powers as powers in trust. Harvard Law Review 44(7), 10491074.

Boons, F. and Luedeke-Freund, F. (2013). Business models for sustainable innovation: state-ofthe-art and steps toward a research agenda. Journal of Cleaner Production 45 (April), 919.

Borland, H., Ambrosini, V., Lindgreen, A. and Vanhamme, J. (2016). Building theory at the intersection of ecological sustainability and strategic management. Journal of Business Ethics, 135, 293-307.

Bowen, H. R. (1953). Social responsibility of the businessman. Harper \& Row, New York, NY. Brandsen, T. and Karré, P. M. (2011). Hybrid organizations: No cause for concern? International Journal of Public Administration 34(13), 827-836.

Brück, T., Naudé, W. and Verwimp, P. (2011). Small business, entrepreneurship and violent conflict in developing countries. Journal of Small Business \& Entrepreneurship 24(2), 161178.

Calton, J. M., Werhane, P. H., Hartman, L. P. and Bevan, D. (2013). Building partnerships to create social and economic value at the base of the global development pyramid. Journal of Business Ethics 117(4), 721-733.

Carroll, A. B. (1999). Corporate social responsibility evolution of a definitional construct. Business \& Society 38(3), 268-295. 
Accepted version status October 2016; Journal of Business Ethics

Carroll, A. B. (1979). A three-dimensional conceptual model of corporate performance. Academy of Management Review 4(4), 497-505.

Chatain, O. (2011). Value creation, competition, and performance in buyer-supplier relationships. Strategic Management Journal 32(1), 76-102.

Corner, P. and Ho, M. (2010). How opportunities develop in social entrepreneurship. Entrepreneurship Theory and Practice 34(4), 635-659.

Corner, P. and Wu, S. (2012). Dynamic capability emergence in the venture creation process. International Small Business Journal 30(2), 138-160.

Crane, A., Palazzo, G., Spence, L. J. and Matten, D. (2014). Contesting the value of "Creating Shared Value', California Management Review 56(2), 130-151.

D'Aunno, T., Sutton, R. I. and Price, R. H. (1991). Isomorphism and external support in conflicting institutional environments: A study of drug abuse treatment units. Academy of Management Journal 34(3), 636-661.

Davis, K. (1960). Can business afford to ignore social responsibilities? California Management Review 2(3), 70-76.

Dees, J. G. (1998). Enterprising nonprofits. Harvard Business Review 76(1), 55-66.

Dembek, K., Singh, P. and Bhakoo, V. (2016). Literature Review of Shared Value: A Theoretical Concept or a Management Buzzword? Journal of Business Ethics 137(2), 231-267.

Dodd, E. M. (1932). For whom are corporate managers trustees? Harvard Law Review 45, 1145 1163.

Doherty, B., Haugh, H. and Lyon, F. (2014). Social enterprises as hybrid organizations: A review and research agenda. International Journal of Management Reviews 16(4), 417-436. 
Accepted version status October 2016; Journal of Business Ethics

Dubois, A. and Gibbert, M. (2010). From complexity to transparency: Managing the interplay between theory, method and empirical phenomena in IMM case studies. Industrial Marketing Management, 39(1), 129-136.

Eisenhardt, K. M. (1989). Building theories from case study research. Academy of Management Review 14(4), 532-550.

Eisenhardt, K. and Martin J. (2000). Dynamic capabilities: What are they? Strategic Management Journal 21(10-11), 1105-1121.

Elkington, J. (1998). Cannibals with forks. New Society Publishers, Gabriola Island, BC.

Ellram, L. M. (1996). The use of the case study method in logistics research. Journal of Business Logistics 17(2), 93-138.

Fallon, N. (2014). What is corporate social responsibility? Business News Daily, February 27, 2014.

Frederick, W. C. (1960). The growing concern over business responsibility. California Management Review 2(4), 54-61.

Freeman, R. and Reed, D. (1983). Stockholders and stakeholders: A new perspective on corporate governance. California Management Review 25(3), 88-106.

Friedman, M. (1970). The social responsibility of business is to increase its profits. The New York Times Magazine, September 13, 1970.

Gawell, M. (2013). Social entrepreneurship-innovative challengers or adjustable followers? Social Enterprise Journal 9(2), 203-220.

Gladwin, T. N., Kennelly, J. J. and Krause, T. S. (1995). Shifting paradigms for sustainable development: Implications for management theory and research. Academy of Management Review 20(4), 874-907. 
Accepted version status October 2016; Journal of Business Ethics

Glavas, A., \& Mish, J. (2015). Resources and Capabilities of Triple Bottom Line Firms: Going Over Old or Breaking New Ground? Journal of Business Ethics, 127(3), 623-642.

Global Footprint Network (2016). Earth Overshoot Day. http://www.footprintnetwork.org/en/index.php/GFN/page/earth_overshoot_day. Accessed October 1, 2016.

Gold, S., Seuring, S. and Beske, P. (2010). Sustainable supply chain management and interorganizational resources: a literature review. Corporate Social Responsibility and Environmental Management 17(4), 230-245.

Greenwood, R. and Suddaby, R. (2006). Institutional entrepreneurship in mature fields: The big five accounting firms. Academy of Management Journal 49(1), 27-48.

Gupta, S., Beninger, S. and Ganesh, J. (2015). A hybrid approach to innovation by social enterprises: lessons from Africa. Social Enterprise Journal 11(1), 89-112.

Hahn, R., and Gold, S. (2014). Resources and governance in "base of the pyramid"-partnerships: Assessing collaborations between businesses and non-business actors. Journal of Business Research 67(7), 1321-1333.

Hart, S. L. (1995). A natural-resource-based view of the firm. Academy of Management Review 20(4), 986-1014.

Hart, S. L. and Dowell, G. (2010). A natural-resource-based view of the firm: Fifteen years after. Journal of Management 37(5), 1464-1479.

Hart, S. and Milstein, M. B. (2003). Creating sustainable value. Academy of Management Executive 17(2), 56-69.

Hassini, E., Surti, C., and Searcy, C. (2012). A literature review and a case study of sustainable supply chains with a focus on metrics. International Journal of Production Economics, 140(1), 69-82. 
Accepted version status October 2016; Journal of Business Ethics

Haugh, H. (2005). A research agenda for social entrepreneurship. Social Enterprise Journal 1(1), $1-12$.

Hunt, S. D. and Morgan, R. M. (1995). The comparative advantage theory of competition. The Journal of Marketing 59(2), 1-15.

Hussain, N., Rigoni, U., \& Orij, R. P. (2016). Corporate Governance and Sustainability Performance: Analysis of Triple Bottom Line Performance. Journal of Business Ethics, 122.

Jay, J. (2013). Navigating paradox as a mechanism of change and innovation in hybrid organizations. Academy of Management Journal 56, 137-159.

Jenkins, B. and Fries, L. (2012). PROJECT NURTURE: Partnering for Business Opportunity and Development Impact. The CSR Initiative at the Harvard Kennedy School, Cambridge, MA.

Jick, T. D. (1979). Mixing qualitative and quantitative methods: Triangulation in action. Administrative Science Quarterly 24, 602-611.

Jo, H. and Maretno, A. H. (2011). Corporate governance and firm value: The impact of corporate social responsibility. Journal of Business Ethics 103(3), 351-383.

Jones Christensen, L., Siemsen, E., and Balasubramanian, S. (2015). Consumer behavior change at the base of the pyramid: Bridging the gap between for-profit and social responsibility strategies. Strategic Management Journal, 36(2), 307-317.

Juran, J. M. (1995). A history of managing for quality: The evolution, trends, and future directions of managing for quality. ASQC Quality press, Milwaukee, WI.

Ketokivi, M. and Choi, T. (2014). The renaissance of case research as a scientific method. Journal of Operations Management 32(5), 232-240. 
Accepted version status October 2016; Journal of Business Ethics

Khanna, T. and Yafeh, Y. (2005). Business groups in emerging markets: Paragons or parasites? ECGI-Finance Working Paper 92.

Klassen, R. D. and Vachon, S. (2003). Collaboration and evaluation in the supply chain: the impact on plant-level environmental investment. Production and Operations Management 12(3), 336-352.

Klassen, R. D. and Vereecke, A. (2012). Social issues in supply chains: capabilities link responsibility, risk (opportunity), and performance. International Journal of Production Economics 140(1), 103-115.

Kleindorfer, P. R., Singhal, K. and Wassenhove, L. N. (2005). Sustainable operations management. Production and Operations Management 14(4), 482-492.

Kolk, A., and Lenfant, F. (2015). Cross-Sector Collaboration, Institutional Gaps, and Fragility: The Role of Social Innovation Partnerships in a Conflict-Affected Region. Journal of Public Policy \& Marketing 34(2), 287-303.

Lee, J. L., Mitchell, T. R., and Sablynski, C. J. (1999). Qualitative Research in Organizational and Vocational Psychology, 1979-1999. Journal of Vocational Behavior 55(2), 161-187.

Lepoutre, J. and Aimé, H. (2006). Investigating the impact of firm size on small business social responsibility: a critical review. Journal of Business Ethics 67(3), 257-273.

Lisi, I. E. (2016). Determinants and Performance Effects of Social Performance Measurement Systems. Journal of Business Ethics, 1-27.

London, T., and Hart, S. L. (2011). Creating a fortune with the base of the pyramid. Next generation business strategies for the base of the pyramid, 1-18.

Longoni, A., \& Cagliano, R. (2016). Sustainable Innovativeness and the Triple Bottom Line: The Role of Organizational Time Perspective. Journal of Business Ethics, 1-24. 
Accepted version status October 2016; Journal of Business Ethics

Lyons, T. (2013). The Role of Social Entrepreneurship in Sustainable Business. http://www.triplepundit.com/2013/09/role-social-entrepreneurship-sustainable-business. Accessed December 2, 2014.

Mahoney, J. T., and Pandian, J. R. (1992). The resource-based view within the conversation of strategic management. Strategic Management Journal, 13(5), 363-380.

Mair, J. and Martí, I. (2006). Social entrepreneurship research: a source of explanation, prediction, and delight. Journal of World Business 41(1), 36-44.

Maltz, E. and Schein, S. (2012). Cultivating shared value initiatives: A three Cs Approach. Journal of Corporate Citizenship 47, 55-74.

Matos, S. and Silvestre, B.S. (2013). Managing stakeholder relations when developing sustainable business models: The case of the Brazilian energy sector. Journal of Cleaner Production 45 (20), 61-73.

Meehan, J., Meehan, K. and Richards, A. (2006). Corporate social responsibility: the 3C-SR model. International Journal of Social Economics 33(5/6), 386-398.

Minkoff, D. C. (2002). The emergence of hybrid organizational forms: Combining identity-based service provision and political action. Nonprofit and voluntary sector quarterly 31(3), $377-401$.

Montabon, F., Pagell, M. and Wu, Z. (2016). Making sustainability sustainable. Journal of Supply Chain Management 52(2), 11-27.

Moore, D., Cranston, G., Reed, A. and Galli, A. (2012). Projecting future human demand on the Earth's regenerative capacity. Ecological Indicators. 16, 3-10.

Murphy, P. J. and Coombes, S. M. (2009). A model of social entrepreneurial discovery. Journal of Business Ethics 87, 325-336. 
Accepted version status October 2016; Journal of Business Ethics

Naude, W., Santos-Paulino, A. and McGillivray, M. (2009). Measuring Vulnerability: An Overview and Introduction, Oxford Development Studies. Taylor \& Francis Journals 37(3), 183-191.

Norman, W. and MacDonald, C. (2004). Getting to the bottom of 'triple bottom line. Business Ethics Quarterly 14(2), 243-62.

Normann, R. and Ramirez, R. (1993). From Value Chain to Value Constellation: Designing Interactive Strategy. Harvard Business Review 71(July/Aug), 65-77.

Pache, A.C. and Santos, F. (2012). Inside the hybrid organization: selective coupling as a response to competing institutional logics. Academy of Management Journal 56, $972-$ 1001.

Pagell, M. and Wu, Z. (2009). Building a more complete theory of sustainable supply chain management using case studies of 10 exemplars. Journal of Supply Chain Management 45(2), 37-56.

Peteraf, M. A. (1993). The cornerstones of competitive advantage: a resource-based view. Strategic Management Journal, 14(3), 179-191.

Porter, M. E. and Kramer, M. R. (2011). Creating shared value. Harvard Business Review $89(1 / 2), 62-77$.

Porter, M. E. and Kramer, M. R. (2006). Strategy and society. The link between competitive advantage and corporate social responsibility. Harvard Business Review 84(12), 78-92.

Prahalad, C.K., and Hamel, G. (1990). The core competence of the corporation. Harvard Business Review, 68(3), 79-91.

Rotheroe, N. C. and Miller, L. (2008). Innovation in social enterprise: achieving a user participation model. Social Enterprise Journal 4(3), 242-260. 
Accepted version status October 2016; Journal of Business Ethics

Santos, F. M. (2012). A positive theory of social entrepreneurship. Journal of Business Ethics $111,335-351$.

Searcy, C. (2012). Corporate sustainability performance measurement systems: A review and research agenda. Journal of Business Ethics 107(3), 239-253.

Selsky, J. W., and Parker, B. (2005). Cross-sector partnerships to address social issues: Challenges to theory and practice. Journal of Management, 31(6), 849-873.

Serenko, A. and Bontis, N. (2009). A citation-based ranking of the business ethics scholarly journals. International Journal of Business Governance and Ethics 4(4), 390-399.

Spear, R., Moreau, C. and Mertens, S. (2013). Managers' competences in social enterprises: which specificities? Social Enterprise Journal 9(2), 164-183.

Tate, W. L., Ellram, L. M. and Kirchoff, J. F. (2010). Corporate social responsibility reports: a thematic analysis related to supply chain management. Journal of Supply Chain Management 46(1), 19-44.

Teece, D. J., Pisano, A. and Shuen, A. (1997). Dynamic capabilities and strategic management. Strategic Management Journal 18(7), 509-533.

Thake, S. and Zadek, S. (1997). Practical people, noble causes. How to support community based social entrepreneurs. New Economics Foundation, London.

Torugsa, N. A., O’Donohue, W. and Hecker, R. (2012). Capabilities, proactive CSR and financial performance in SMEs: Empirical evidence from an Australian manufacturing industry sector. Journal of Business Ethics 109(4), 483-500.

Tracey, P., Phillips, N. and Jarvis, O. (2011). Bridging institutional entrepreneurship and the creation of new organizational forms: a multilevel model. Organization Science 22, 6080. 
Accepted version status October 2016; Journal of Business Ethics

Wacker, J. G. (1998). A definition of theory: research guidelines for different theory-building research methods in operations management. Journal of Operations Management 16(4), 361-385.

Wagner, T., Lutz, R. J. and Weitz, B. A. (2009). Corporate hypocrisy: Overcoming the threat of inconsistent corporate social responsibility perceptions. Journal of Marketing 73(6), 7791.

Weerawardena, J. and Mort, G. S. (2006). Investigating social entrepreneurship: a multidimensional model. Journal of World Business 41, 21-35.

Wernerfelt, B. (1984). A resource-based view of the firm. Strategic Management Journal 5(2), 171-180.

Wilson, F., and Post, J. E. (2013). Business models for people, planet (\& profits): exploring the phenomena of social business, a market-based approach to social value creation. Small Business Economics, 40(3), 715-737.

World Bank (2015). Poverty Overview. http://www.worldbank.org/en/topic/poverty/overview\#1. Accessed on May 31, 2015.

Yin, R. K. (2009). Case study research: Design and methods (4th edition). Sage, New York, NY.YSB (2014). Yunus Social Business Investors Brochure, 1-16.

YSB (2014), Yunus Social Business Investors Brochure, 1-16.

Yunus, M., Moingeon, B. and Lehmann-Ortega, L. (2010). Building social business models: Lessons from the Grameen experience. Long Range Planning 43(2), 308-325.

Zahra, S. A., Gedajlovic, E., Neubaum, D. O. and Shulman, J. M. (2009). A typology of social entrepreneurs: motives, search processes and ethical challenges. Journal of Business Venturing 24(5), 519-532. 


\section{FIGURES AND TABLES}

FIGURE 1

The RBV (adapted from Hart, 1995, p. 988)

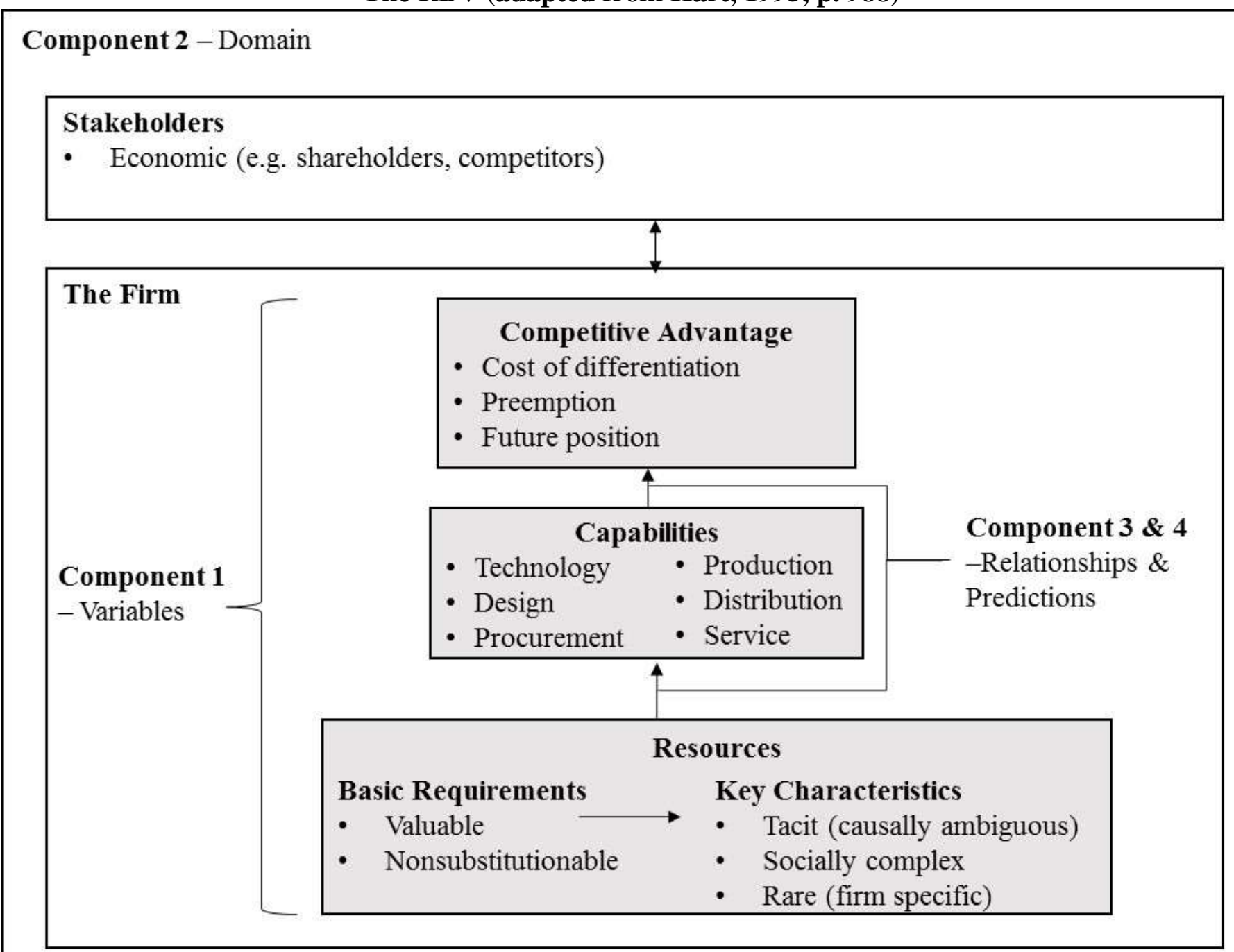


FIGURE 2

The NRBV summarized (further adapted from Hart, 1995, p. 988 and Hart and Dowell, 2010, p. 1472)

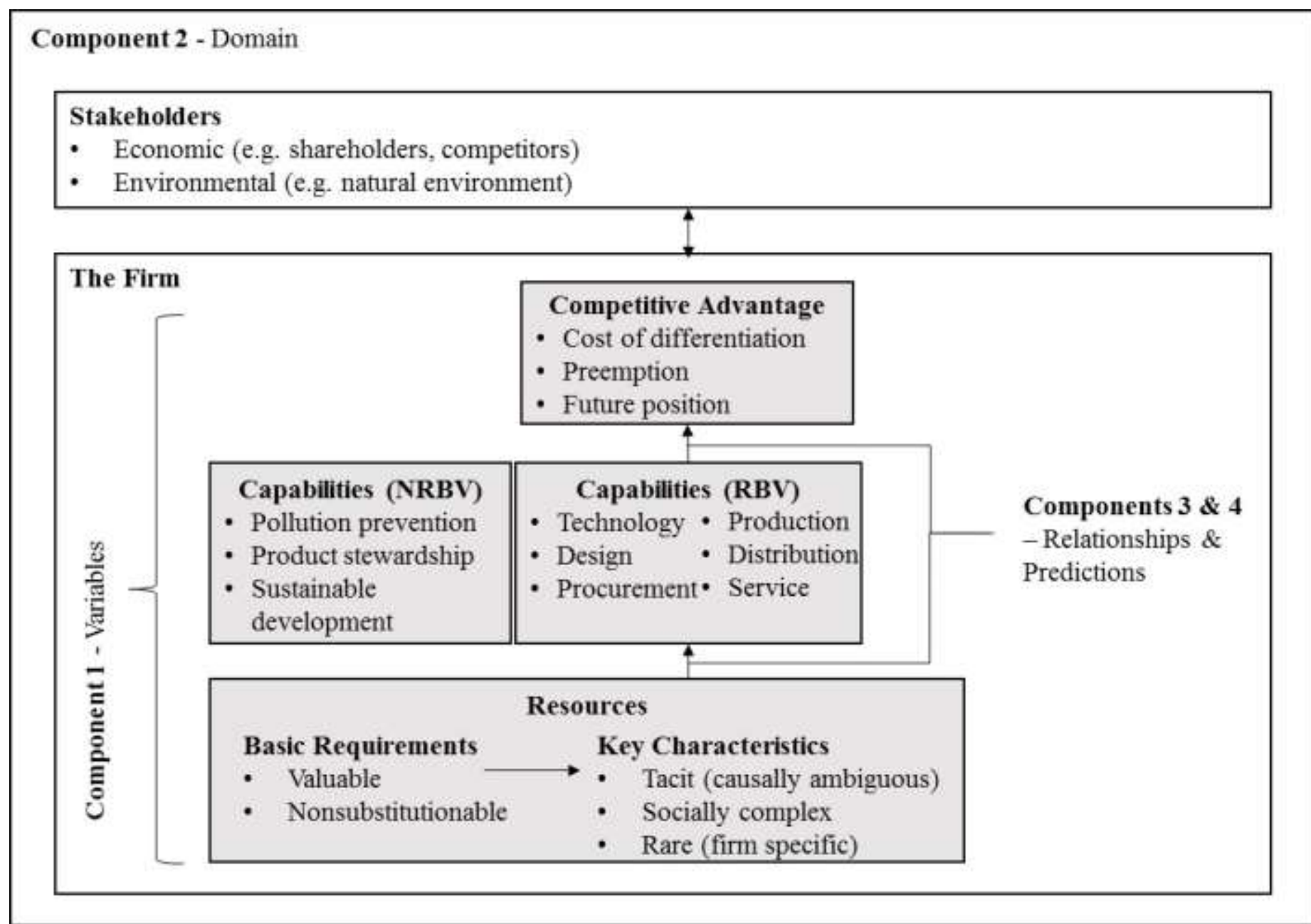


FIGURE 3

Toward an emergent SRBV (complementing RBV and NRBV), own illustration

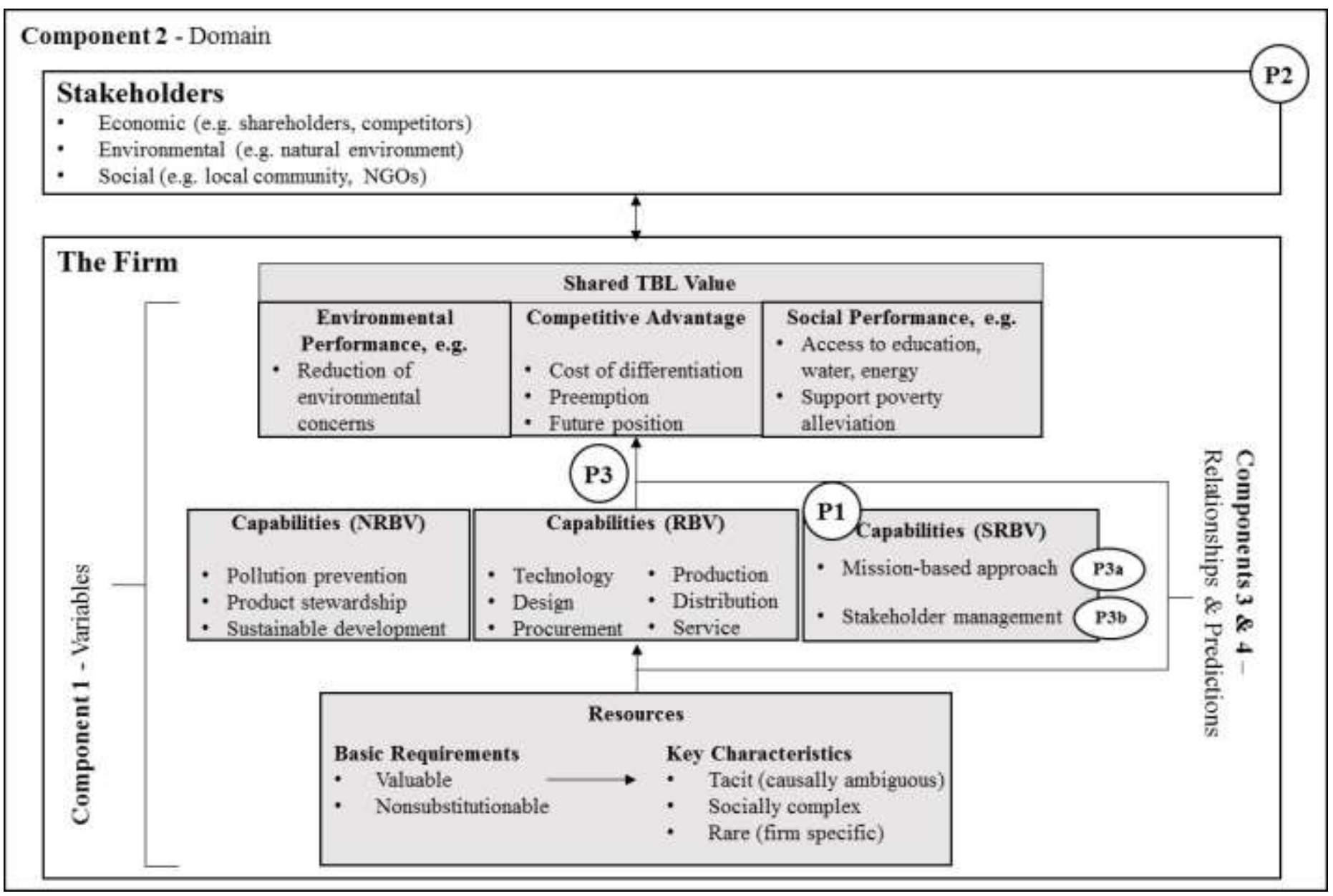




\section{TABLE 1}

Natural Resource-based View: Conceptual framework (Hart, 1995, p. 992)

\begin{tabular}{|c|c|c|c|}
\hline Strategic capability & $\begin{array}{c}\text { Environmental } \\
\text { Driving Force }\end{array}$ & Key Resource & $\begin{array}{c}\text { Competitive } \\
\text { Advantage }\end{array}$ \\
\hline Pollution Prevention & $\begin{array}{c}\text { Minimize emissions, } \\
\text { effluents, and waste }\end{array}$ & $\begin{array}{c}\text { Continuous } \\
\text { improvement }\end{array}$ & Lower costs \\
\hline Product Stewardship & $\begin{array}{c}\text { Minimize life-cycle } \\
\text { cost of products }\end{array}$ & $\begin{array}{c}\text { Stakeholder } \\
\text { integration }\end{array}$ & Preempt competitors \\
\hline Sustainable & $\begin{array}{c}\text { Minimize } \\
\text { environmental } \\
\text { burden of firm } \\
\text { growth and } \\
\text { development }\end{array}$ & Shared vision & Future positions \\
\hline
\end{tabular}


TABLE 2

Illustration of social capabilities from literature

\begin{tabular}{|c|c|}
\hline Social Capability & Literature \\
\hline - Mission-driven approach & $\begin{array}{l}\text { Maltz and Schein 2012; } \\
\text { Dees 1998; Spear et al. } \\
\text { 2013; Torugsa et al. 2012; } \\
\text { Glavas and Mish } 2015\end{array}$ \\
\hline $\begin{array}{l}\text { - Know, understand and mobilize internal governance } \\
\text { system and develop metrics to drive right behavior }\end{array}$ & $\begin{array}{l}\text { Haugh 2005; Spear et al. } \\
\text { 2013; Glavas and Mish } \\
2015\end{array}$ \\
\hline - Manage staff and volunteers & Spear et al. 2013 \\
\hline - (Social) Innovation & $\begin{array}{l}\text { Klassen and Vereecke } \\
2012\end{array}$ \\
\hline $\begin{array}{l}\text { - Understanding and addressing the needs of those at } \\
\text { the BoP; able to position in social economy } \\
\text { membership and take pride }\end{array}$ & $\begin{array}{l}\text { Hart and Dowell 2010; } \\
\text { Spear et al. } 2013\end{array}$ \\
\hline $\begin{array}{l}\text { - Develop a strategy/social model that can sustain the } \\
\text { social enterprises' multiple goals }\end{array}$ & $\begin{array}{l}\text { Spear et al. 2013; Klassen } \\
\text { and Vereecke 2012; Dees, } \\
\text { 1998; Spear et al. 2013; } \\
\text { Corner and Ho 2010 }\end{array}$ \\
\hline $\begin{array}{l}\text { - Manage conflicting institutional goals, structures } \\
\text { and processes }\end{array}$ & Pache and Santos 2012 \\
\hline $\begin{array}{l}\text { - (Supply/Value Chain) collaboration in terms of } \\
\text { suppliers and/or financial partners } \\
\text { (Funding/Credit/Microfinancing) }\end{array}$ & $\begin{array}{l}\text { Klassen and Vereecke } \\
\text { 2012; Maltz and Schein } \\
\text { 2012; Meehan et al. 2006; } \\
\text { Jay 2013; Calton et al. } \\
\text { 2013; Porter and Kramer } \\
\text { 2011; Spear et al. 2013; } \\
\text { Glavas and Mish 2015 }\end{array}$ \\
\hline - (Supply Chain) Monitoring & $\begin{array}{l}\text { Klassen and Vereecke } \\
\text { 2012; Glavas and Mish } \\
2015\end{array}$ \\
\hline - Manage the various external stakeholders & $\begin{array}{l}\text { Spear et al. 2013; Tracey et } \\
\text { al. 2011; Torugsa et al. } \\
2012\end{array}$ \\
\hline
\end{tabular}


TABLE 3

Case Overview

\begin{tabular}{|c|c|c|c|}
\hline $\begin{array}{l}\text { Case/ } \\
\text { Interviewee }\end{array}$ & Business Description & Entrepreneur's Background & Major Stakeholders and Their Role \\
\hline $\begin{array}{l}\text { YSB } \\
\text { Interviewee A } \\
\text { Haiti Country } \\
\text { Manager }\end{array}$ & See Appendix A & & \\
\hline $\begin{array}{l}\text { Case } 1 \\
\text { "Energy } \\
\text { Products } \\
\text { (EPRO)" } \\
\text { Interviewee B } \\
\text { Founder }\end{array}$ & $\begin{array}{l}\text { It had } 8 \text { employees at the time the interviews } \\
\text { were conducted and a need for } 5 \text { additional } \\
\text { employees. } \\
\text { The sales model revolves around operating a } \\
\text { number of flagship stores and also distributing } \\
\text { these products via trucks and motorbikes to a } \\
\text { network of retailers around the country. }\end{array}$ & $\begin{array}{l}\text { The entrepreneur who was interviewed has been } \\
\text { part of this project for approximately two years. } \\
\text { He is originally trained as an agronomist and } \\
\text { economist, gathered microfinance experience and } \\
\text { then later also got a degree in energy. His first } \\
\text { social entrepreneurial experiences were in } \\
\text { Lebanon before coming to Haiti. }\end{array}$ & $\begin{array}{l}\text { The business idea for this social business was } \\
\text { inspired and initially seed funded by a European } \\
\text { NGO (ENGO), a microfinance institution operating } \\
\text { in Haiti since 2003. ENGO currently is working in } \\
\text { more than ten countries, with programs and partners } \\
\text { in the areas of microfinance and social } \\
\text { entrepreneurship. What started with an ENGO } \\
\text { program, evolved into EPRO. } \\
\text { Two types of solar lamps are offered and can be used } \\
\text { either in homes or for work. These are both } \\
\text { imported, supplied by Total, or more specifically } \\
\text { "Awango", the social entrepreneurship initiative by } \\
\text { Total. Awango provides these products with } \\
\text { affordable prices to explicitly serve BoP customers. } \\
\text { IDE Microfinance (a microfinance institution) } \\
\text { provides end customers unable to pay the price of } \\
\text { products in one sum with a low-interest credit, gives } \\
\text { them a check, with which the end customer can pay } \\
\text { EPRO. The loan repayments to IDE Microfinance } \\
\text { are then made in small amounts via Western Union, } \\
\text { due to the lack of widespread use of bank accounts. }\end{array}$ \\
\hline
\end{tabular}




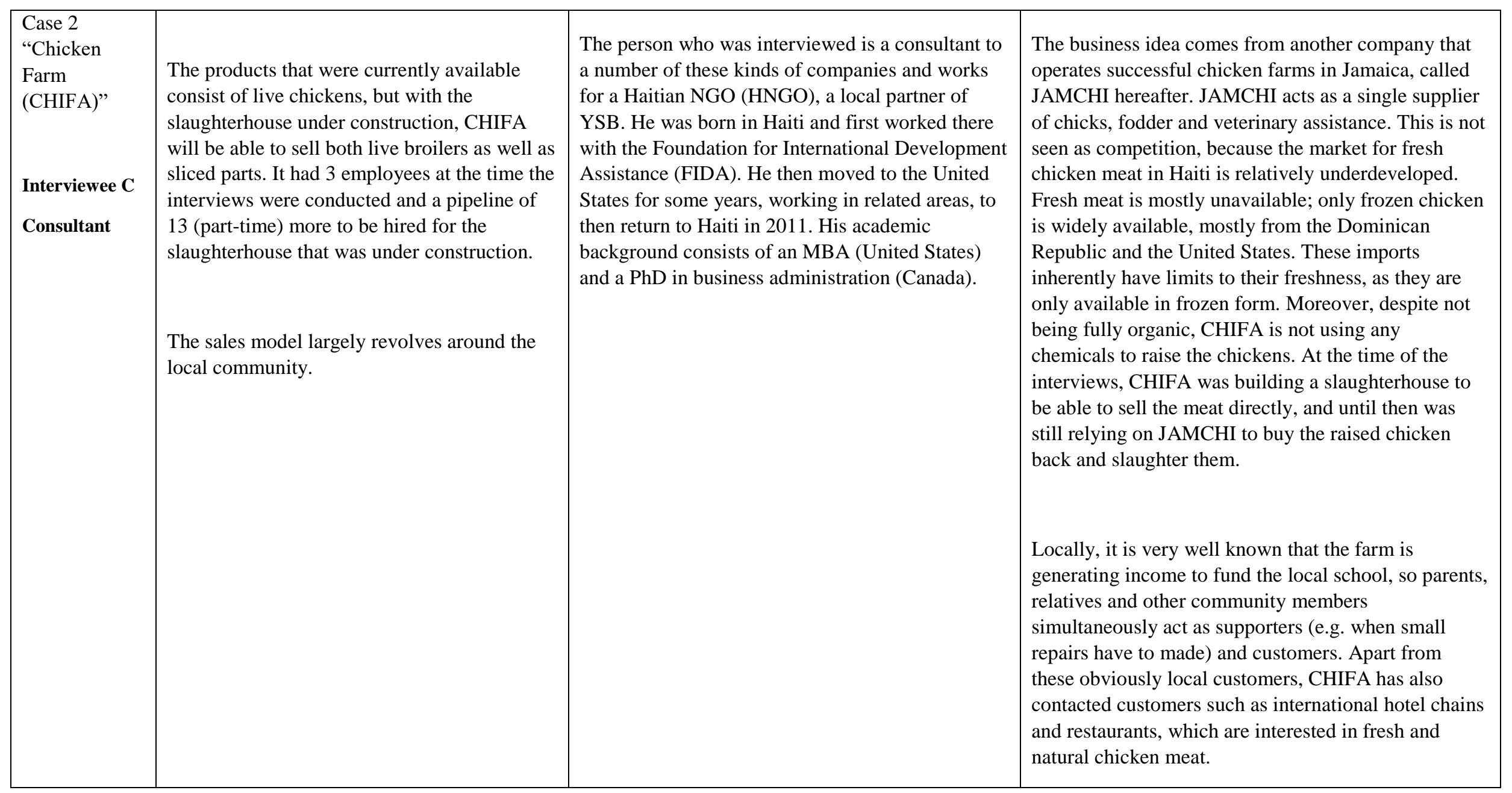




\begin{tabular}{|c|c|c|c|}
\hline $\begin{array}{l}\text { Case } 3 \\
\text { "Cleaning } \\
\text { Products } \\
\text { (CLEAPRO)" } \\
\text { Interviewee D } \\
\text { Founder }\end{array}$ & $\begin{array}{l}\text { CLEAPRO offers the aforementioned } \\
\text { products with the edge that customers can } \\
\text { bring their own packaging, which takes out a } \\
\text { significant part of the costs (for both company } \\
\text { and customers). } \\
\text { CLEAPRO had about } 10 \text { full time employees } \\
\text { at the time the interviews were conducted. }\end{array}$ & $\begin{array}{l}\text { The CFO who was interviewed has been part of } \\
\text { the business from the beginning (during 2014) and } \\
\text { prior to that was involved in manufacturing at the } \\
\text { parent company the year before. He has a } \\
\text { background on Wall Street and in a private equity } \\
\text { fund in Haiti. He also holds an MBA (United } \\
\text { States). The main motivation for the CFO resides } \\
\text { in the belief that money can be used to deliver the } \\
\text { right products at the right price to promote social } \\
\text { good and the recognition that most corporations } \\
\text { only put aside a minuscule proportion for social } \\
\text { causes. }\end{array}$ & $\begin{array}{l}\text { Here, the inspiration also came from another company } \\
\text { in Jamaica, called JAMPRO. One of the main funders } \\
\text { is a local Haitian manufacturer of the products and it } \\
\text { acts as a single supplier to CLEAPRO. The social } \\
\text { business is also directly co-located close to the } \\
\text { warehouse of the manufacturing plant and also hosts a } \\
\text { joint ordering and sales team with the manufacturer. }\end{array}$ \\
\hline
\end{tabular}


TABLE 4

Overview on capabilities leveraged in the cases

\begin{tabular}{|c|c|c|c|}
\hline & EPRO & CLEAPRO & CHIFA \\
\hline \multicolumn{4}{|l|}{ RBV } \\
\hline Top Line Revenue Mgmt. (e.g. marketing plan) & $\mathrm{Y}$ & $\mathrm{Y}$ & $\mathrm{Y}$ \\
\hline Product innovation (affordable products, not free because free has no value) & $\mathrm{Y}$ & $\mathrm{Y}$ & $\mathrm{Y}$ \\
\hline Brand Management/Reputation (use of social media; radio etc.) & $\mathrm{Y}$ & $\mathrm{N}$ & $\mathrm{Y}$ \\
\hline Distribution (in line with local context) & $\mathrm{Y}$ & $\mathrm{Y}$ & $\mathrm{Y}$ \\
\hline \multicolumn{4}{|l|}{ NRBV } \\
\hline Pollution prevention & $\mathrm{Y}$ & $\mathrm{Y}$ & $\mathrm{Y}$ \\
\hline Product stewardship (care for product lifecycle) & $\mathrm{Y}$ & $\mathrm{Y}$ & $\mathrm{Y}$ \\
\hline Sustainable Development (care for environmental impact) & $\mathrm{Y}$ & $\mathrm{Y}$ & $\mathrm{Y}$ \\
\hline \multicolumn{4}{|l|}{ SRBV } \\
\hline Mission-driven approach (commitment of entrepreneur at inception) & $\mathrm{Y}$ & $\mathrm{Y}$ & $\mathrm{Y}$ \\
\hline Mission-driven approach (relentlessly pursuing the mission over time) & $\mathrm{Y}$ & $\mathrm{Y}$ & $\mathrm{Y}$ \\
\hline $\begin{array}{l}\text { Exhibiting a heightened sense of accountability/awareness for internal } \\
\text { governance and metrics to drive right behavior }\end{array}$ & Y & Y & Y \\
\hline $\begin{array}{l}\text { Social Innovation/Model Design (Project Business Plan Development; with } \\
\text { TBL goals and including a supply/value chain partner network) }\end{array}$ & $\mathrm{Y}$ & $\mathrm{Y}$ & Y \\
\hline $\begin{array}{l}\text { (Supply/Value Chain) Collaboration in terms of financial partners } \\
\text { (Funding/Credit/Microfinancing) }\end{array}$ & $\mathrm{Y}$ & $\mathrm{N}$ & $\mathrm{Y}$ \\
\hline (Supply/Value Chain) Collaboration (for products) & $\mathrm{N}$ & $\mathrm{N}$ & $\mathrm{Y}$ \\
\hline
\end{tabular}


TABLE 5

Mission-based approach and stakeholder management capability constructs

\begin{tabular}{|c|c|c|}
\hline Case & $\begin{array}{l}\text { Capability } \\
\text { construct }\end{array}$ & Examples from interviews \\
\hline EPRO & $\begin{array}{l}\text { Mission-based } \\
\text { approach }\end{array}$ & $\begin{array}{l}\text { In his words: "I am sure that access to energy in different countries is one of the } \\
\text { biggest challenges we have to face, and I wanted to be a part of the solution." } \\
\text { (Interviewee B). In line with this, when asked about the success criteria in EPRO's } \\
\text { case, the answer was to provide energy to those who do not yet have access. }\end{array}$ \\
\hline CHIFA & $\begin{array}{l}\text { Mission-based } \\
\text { approach }\end{array}$ & $\begin{array}{l}\text { Interviewee } \mathrm{C} \text { sees an opportunity to empower people with such a kind of business } \\
\text { and thereby make a difference. }\end{array}$ \\
\hline CLEAPRO & $\begin{array}{l}\text { Mission-based } \\
\text { approach }\end{array}$ & $\begin{array}{l}\text { Although he (Interviewee D) clearly regards financial viability as a key priority, he } \\
\text { also revealed a further mission behind the business "I think initially I would describe } \\
\text { it as sustainability of the business. Breaking even [economic sustainability], which we } \\
\text { are not there yet. To me, it would be the first success, and hopefully after that we } \\
\text { continue to achieve it. Breaking even, being able to sustain the business over the long } \\
\text { run, being able to reinvest in other interesting projects and being able to provide some } \\
\text { money for schools and students and things like that." With this notion of reinvesting } \\
\text { even beyond the social scope of the business as such, the different perspective of this } \\
\text { type of business becomes apparent. }\end{array}$ \\
\hline EPRO & $\begin{array}{l}\text { Stakeholder } \\
\text { Management }\end{array}$ & $\begin{array}{l}\text { USAid organized different stakeholders of the value chain. They organized joint } \\
\text { workshops and "now everybody knows everybody in that area" (Interviewee B). They } \\
\text { also actively influenced the [NGO], so they were not giving out free products, but } \\
\text { instead selling them at cost. }\end{array}$ \\
\hline CHIFA & $\begin{array}{l}\text { Stakeholder } \\
\text { Management }\end{array}$ & $\begin{array}{l}\text { NGOs are seen as partners for sharing resources. Networking is seen as essential, also } \\
\text { with other businesses in other countries. }\end{array}$ \\
\hline CLEAPRO & $\begin{array}{l}\text { Stakeholder } \\
\text { Management }\end{array}$ & $\begin{array}{l}\text { For example, partnered with water kiosks to try to distribute to the network. Want to } \\
\text { work with the government in future to influence overall Haitian water system. }\end{array}$ \\
\hline
\end{tabular}


TABLE 6

Overview on stakeholders' inputs at the three social businesses

\begin{tabular}{|c|c|c|c|c|}
\hline \multicolumn{4}{|l|}{ Case EPRO } & \multirow[b]{2}{*}{$\begin{array}{l}\text { Context } \\
\text { Shaping }\end{array}$} \\
\hline Stakeholders & Funding & Expertise & Products & \\
\hline Financial Institution 1 & $\mathrm{Y}$ & $\mathrm{N}$ & $\mathrm{N}$ & $\mathrm{N}$ \\
\hline Financial Institution 2 & $\mathrm{Y}$ & $\mathrm{N}$ & $\mathrm{N}$ & $\mathrm{N}$ \\
\hline OFID & $\mathrm{Y}$ & $\mathrm{N}$ & $\mathrm{N}$ & $\mathrm{N}$ \\
\hline AFD & $\mathrm{Y}$ & $\mathrm{N}$ & $\mathrm{N}$ & $\mathrm{N}$ \\
\hline NGO1 & $\mathrm{Y}$ & $\mathrm{N}$ & $\mathrm{N}$ & $\mathrm{N}$ \\
\hline French Embassy & $\mathrm{Y}$ & $\mathrm{N}$ & $\mathrm{N}$ & $\mathrm{N}$ \\
\hline USAID & $\mathrm{Y}$ & $\mathrm{N}$ & $\mathrm{N}$ & $\mathrm{Y}$ \\
\hline ICTP & $\mathrm{Y}$ & $\mathrm{N}$ & $\mathrm{N}$ & $\mathrm{Y}$ \\
\hline Suppliers & $\mathrm{N}$ & $\mathrm{N}$ & $\mathrm{Y}$ & Y \\
\hline Total SA (Awango) & $\mathrm{N}$ & $\mathrm{Y}$ & $\bar{Y}$ & $\mathrm{Y}$ \\
\hline PUM Expert & $\mathrm{N}$ & $\mathrm{Y}$ & $\mathrm{N}$ & $\mathrm{N}$ \\
\hline ENGO & $\bar{Y}$ & $\mathrm{Y}$ & $\mathrm{N}$ & $\mathrm{N}$ \\
\hline Grameen Crédit Agricole & $\mathrm{Y}$ & $\mathrm{Y}$ & $\mathrm{N}$ & $\mathrm{N}$ \\
\hline YSB & $\mathrm{Y}$ & $\mathrm{Y}$ & $\mathrm{N}$ & $\mathrm{N}$ \\
\hline \multicolumn{5}{|l|}{ Case CHIFA } \\
\hline Stakeholders & Funding & Expertise & Products & $\begin{array}{l}\text { Context } \\
\text { Shaping }\end{array}$ \\
\hline Private Customers & $\mathrm{Y}$ & $\mathrm{N}$ & $\mathrm{N}$ & $\mathrm{N}$ \\
\hline Hotels & $\mathrm{Y}$ & $\mathrm{N}$ & $\mathrm{N}$ & $\mathrm{N}$ \\
\hline Heifer & $\mathrm{N}$ & $\mathrm{Y}$ & $\mathrm{N}$ & $\mathrm{N}$ \\
\hline Ministry of animal production & $\mathrm{N}$ & $\mathrm{N}$ & $\mathrm{N}$ & Y \\
\hline U.S. and Dominican Republic & $\mathrm{N}$ & $\mathrm{N}$ & $\mathrm{N}$ & $\mathrm{Y}$ \\
\hline JAMCHI & $\mathrm{Y}$ & $\mathrm{Y}$ & $\mathrm{Y}$ & $\mathrm{N}$ \\
\hline Grameen creative lab & $\mathrm{N}$ & $\mathrm{Y}$ & $\mathrm{N}$ & $\mathrm{N}$ \\
\hline Local Community & $\mathrm{Y}$ & $\mathrm{Y}$ & $\mathrm{N}$ & $\mathrm{N}$ \\
\hline HNGO & $\mathrm{Y}$ & $\mathrm{Y}$ & $\mathrm{N}$ & $\mathrm{N}$ \\
\hline$Y S B$ & $\bar{Y}$ & $\mathrm{Y}$ & $\mathrm{N}$ & $\mathrm{N}$ \\
\hline \multicolumn{5}{|l|}{ Case CLEAPRO } \\
\hline Stakeholders & Funding & Expertise & Products & $\begin{array}{l}\text { Context } \\
\text { Shaping }\end{array}$ \\
\hline Water Kiosks & $\mathrm{Y}$ & $\mathrm{N}$ & $\mathrm{N}$ & $\mathrm{N}$ \\
\hline Private companies and hospitals & $\bar{Y}$ & $\mathrm{~N}$ & $\mathrm{~N}$ & $\mathrm{~N}$ \\
\hline Sellers (POS) & $\mathrm{Y}$ & $\mathrm{N}$ & $\mathrm{N}$ & $\mathrm{N}$ \\
\hline Sellers & $\mathrm{Y}$ & $\mathrm{N}$ & $\mathrm{N}$ & $\mathrm{Y}$ \\
\hline USAID & $\mathrm{N}$ & $\mathrm{N}$ & $\mathrm{N}$ & Y \\
\hline Government (water system) & $\mathrm{N}$ & $\mathrm{N}$ & $\mathrm{N}$ & $\mathrm{Y}$ \\
\hline JAMPRO & $\mathrm{N}$ & $\mathrm{Y}$ & $\mathrm{Y}$ & $\mathrm{N}$ \\
\hline Logistics consultant & $\mathrm{N}$ & $\mathrm{Y}$ & $\mathrm{N}$ & $\mathrm{N}$ \\
\hline Unicef partner & $\mathrm{N}$ & $\mathrm{Y}$ & $\mathrm{N}$ & $\mathrm{N}$ \\
\hline Manufacturing (parent) company & $\mathrm{Y}$ & $\mathrm{Y}$ & $\mathrm{Y}$ & $\mathrm{N}$ \\
\hline$Y S B$ & $\mathrm{Y}$ & $\mathrm{Y}$ & $\mathrm{N}$ & $\mathrm{N}$ \\
\hline
\end{tabular}


TABLE 7

Shared TBL Value Objectives Across the Cases

\begin{tabular}{|c|c|c|c|c|c|}
\hline TBL Factor & Outcomes & EPRO & CLEAPRO & CHIFA & \multirow{6}{*}{$\begin{array}{c}\text { Shared } \\
\text { TBL } \\
\text { Value }\end{array}$} \\
\hline \multirow[t]{2}{*}{ Environmental } & $\begin{array}{l}\text { Reduction in emission, } \\
\text { effluents and waste }\end{array}$ & $\begin{array}{l}\text { Main objective: Participating in the } \\
\text { voluntary carbon finance market. }\end{array}$ & $\begin{array}{l}\text { Main objective: Reduce solid waste in } \\
\text { Haiti through the reuse/recycling of plastic } \\
\text { bottles and increase awareness of } \\
\text { environmental issues at the community } \\
\text { level. All elaborated with specific } \\
\text { measures on how to reach these objectives, } \\
\text { as well as indicators and means and } \\
\text { frequency of verification. }\end{array}$ & $\begin{array}{l}\text { Further objective: Avoidance of } \\
\text { chemicals in the chicken meat production } \\
\text { as well as the use of the chicken waste as } \\
\text { fertilizer for agriculture are worth noting; } \\
\text { also the overall supply chain is much } \\
\text { shorter in comparison to the frozen } \\
\text { imports, which have to be transported } \\
\text { and chilled over long distances, having a } \\
\text { significant environmental target. }\end{array}$ & \\
\hline & $\begin{array}{l}\text { Reduction of other } \\
\text { environmental concerns } \\
\text { (e.g. non-compliance, use } \\
\text { of non-renewable } \\
\text { resources) }\end{array}$ & $\begin{array}{l}\text { Further objective: From an } \\
\text { environmental perspective, } \\
\text { deforestation is a tremendous issue in } \\
\text { Haiti and charcoal is - although illegal } \\
\text { - largely coming from the last one- } \\
\text { digit percentage of native woods. The } \\
\text { solar lamps that are available also } \\
\text { promote the turn to a renewable } \\
\text { energy source. }\end{array}$ & & & \\
\hline \multirow[t]{3}{*}{ Economic } & Higher revenue & $\begin{array}{l}\text { Basic objective: Reach break-even as } \\
\text { planned. }\end{array}$ & $\begin{array}{l}\text { Basic objective: Reach break-even as } \\
\text { planned. }\end{array}$ & $\begin{array}{l}\text { Basic objective: Reach break-even as } \\
\text { planned. }\end{array}$ & \\
\hline & Higher profits & $\begin{array}{l}\text { Basic objective: Reach profit goals as } \\
\text { planned. }\end{array}$ & $\begin{array}{l}\text { Basic objective: Reach profit goals as } \\
\text { planned. }\end{array}$ & $\begin{array}{l}\text { Basic objective: Reach profit goals as } \\
\text { planned. }\end{array}$ & \\
\hline & $\begin{array}{l}\text { Product innovation } \\
\text { (affordable) }\end{array}$ & & $\begin{array}{l}\text { Further objective: The company offers } \\
\text { products which are only at about } 30 \% \text { of } \\
\text { the usual price, giving families economic } \\
\text { access to hygiene products or leaving } \\
\text { families with higher disposable income for } \\
\text { something else }\end{array}$ & & \\
\hline
\end{tabular}




\begin{tabular}{|c|c|c|c|c|c|}
\hline $\begin{array}{l}\text { TBL } \\
\text { Factor }\end{array}$ & Outcomes & EPRO & CLEAPRO & CHIFA & \\
\hline \multirow{6}{*}{ Social } & $\begin{array}{l}\text { Community } \\
\text { Target }\end{array}$ & $\begin{array}{l}\text { Further objective: The products leave the customers } \\
\text { with better economic prospects (so they can accrue } \\
\text { income for other purposes like education). }\end{array}$ & $\begin{array}{l}\text { Further objective: The company offers } \\
\text { products which are only at about } 30 \% \text { of } \\
\text { the usual price, giving families economic } \\
\text { access to hygiene products or leaving } \\
\text { families with higher disposable income for } \\
\text { something else }\end{array}$ & $\begin{array}{l}\text { Main objective: Community and } \\
\text { economic development }\end{array}$ & \multirow{6}{*}{$\begin{array}{l}\text { Shared } \\
\text { TBL } \\
\text { Value }\end{array}$} \\
\hline & $\begin{array}{l}\text { Access to } \\
\text { education }\end{array}$ & $\begin{array}{l}\text { Further objective: With the solar lamps, people have } \\
\text { light in the evening to work or study. }\end{array}$ & & $\begin{array}{l}\text { Main objective: Improving the } \\
\text { quality of education within four } \\
\text { schools. }\end{array}$ & \\
\hline & $\begin{array}{l}\text { Access to } \\
\text { energy }\end{array}$ & $\begin{array}{l}\text { Main objective: Making the (energy) products } \\
\text { available through a network of retailers. }\end{array}$ & & & \\
\hline & $\begin{array}{l}\text { Access to } \\
\text { financial } \\
\text { services }\end{array}$ & $\begin{array}{l}\text { Main objective: Offering financial solutions to } \\
\text { different players in the value chain. }\end{array}$ & & & \\
\hline & $\begin{array}{l}\text { Health and } \\
\text { human rights } \\
\text { protection }\end{array}$ & $\begin{array}{l}\text { Further objective: Also, the gas stoves are better } \\
\text { than charcoal as it relates to health concerns. In } \\
\text { support of the health conditions, an illustrative extract } \\
\text { from EPROs business plan: "The consequences of } \\
\text { fuel poverty are dramatic. Harmful emissions of } \\
\text { carbon monoxide and micro particles linked to } \\
\text { traditional cooking methods cause annual } 4 \text { million } \\
\text { premature deaths worldwide" }\end{array}$ & $\begin{array}{l}\text { Main objective: Increase access to } \\
\text { affordable bleach and other cleaning } \\
\text { products to improve household sanitation } \\
\text { and promote better health, hygiene and } \\
\text { other health-seeking behavior. } \\
\text { In support of the health conditions, here is } \\
\text { an illustrative extract from CLEAPRO's } \\
\text { business plan: "'aitit bears a very high } \\
\text { burden of disease, which contributes to } \\
\text { infant and child mortality - which is the } \\
\text { worst in Latin America and the Caribbean. } \\
\text { The disease burden can be directly related } \\
\text { to low levels of water and sanitation } \\
\text { coverage as well as poor household and } \\
\text { personal hygiene practices. For example, } \\
\text { just } 55 \% \text { of households have access to an } \\
\text { improved water source and } 34 \% \text { do not } \\
\text { have access to any type of rudimentary } \\
\text { toilet or latrine, meaning that they practice } \\
\text { open defecation." }\end{array}$ & & \\
\hline & $\begin{array}{l}\text { Transparency of } \\
\text { information }\end{array}$ & $\begin{array}{l}\text { Main objective: Sufficiently informing consumers to } \\
\text { be aware to select the right energy equipment. }\end{array}$ & & & \\
\hline
\end{tabular}


TABLE 8

A Social Resource-based View: Conceptual Framework, own illustration

\begin{tabular}{|l|l|l|l|}
\hline $\begin{array}{l}\text { Strategic } \\
\text { Capability }\end{array}$ & $\begin{array}{l}\text { Social Driving } \\
\text { Force }\end{array}$ & Key Resource & $\begin{array}{l}\text { Shared TBL Value } \\
\text { Creation }\end{array}$ \\
\hline $\begin{array}{l}\text { Mission-driven } \\
\text { approach (at both } \\
\text { inception and over } \\
\text { time) }\end{array}$ & $\begin{array}{l}\text { Maximize social and } \\
\text { environmental } \\
\text { benefits while } \\
\text { breaking even and } \\
\text { becoming profitable } \\
\text { to perpetuate } \\
\text { business model. }\end{array}$ & $\begin{array}{l}\text { Entrepreneur/founding } \\
\text { team vision/mission } \\
\text { (at inception) and } \\
\text { follow through over } \\
\text { time }\end{array}$ & $\begin{array}{l}\text { E.g. Create jobs, } \\
\text { improve health, } \\
\text { protect/improve } \\
\text { environment, be } \\
\text { financially viable. }\end{array}$ \\
\hline $\begin{array}{l}\text { Stakeholder } \\
\text { management }\end{array}$ & $\begin{array}{l}\text { Maximize support in } \\
\text { terms of products, } \\
\text { information and } \\
\text { funds from a broad } \\
\text { stakeholder base. }\end{array}$ & $\begin{array}{l}\text { Stakeholder network's } \\
\text { inputs (products, } \\
\text { information, finance). }\end{array}$ & $\begin{array}{l}\text { Broaden scope of } \\
\text { value creation and } \\
\text { scale up more } \\
\text { quickly. }\end{array}$ \\
\hline
\end{tabular}

TABLE 9

Toward a more comprehensive overview of the variables

\begin{tabular}{|l|l|l|}
\hline 3C-SR area & Social Capability & References \\
\hline $\begin{array}{l}\text { Commitments } \\
\text { (values) }\end{array}$ & Mission-driven approach (initially) & $\begin{array}{l}\text { Maltz and Schein 2012; Dees 1998; } \\
\text { Spear et al. 2013; Torugsa et al. } \\
\text { 2012; Glavas and Mish 2015 }\end{array}$ \\
\hline & $\begin{array}{l}\text { Know, understand and mobilize internal } \\
\text { governance system and develop metrics to } \\
\text { drive right behavior }\end{array}$ & $\begin{array}{l}\text { Haugh 2005; Spear et al. 2013; } \\
\text { Glavas and Mish 2015 }\end{array}$ \\
\hline $\begin{array}{l}\text { Connections (in } \\
\text { value network) }\end{array}$ & Manage staff and volunteers & Klassen and Vereecke 2012 \\
\hline & $\begin{array}{l}\text { Develop a strategy/social model that can } \\
\text { sustain the social enterprises' multiple goals }\end{array}$ & $\begin{array}{l}\text { Spear et al. 2013; Dees 1998; } \\
\text { Corner and Ho 2010; Hart and } \\
\text { Dowell 2010 }\end{array}$ \\
\hline & Value Chain Partner Network Design & Newly identified from cases \\
\hline & $\begin{array}{l}\text { Klassen and Vereecke 2012; Maltz } \\
\text { and Schein 2012; Meehan et al. } \\
\text { 2006; Jay 2013; Calton et al. 2013; } \\
\text { Porter and Kramer 2011; Spear et } \\
\text { al. 2013; Glavas and Mish 2015 }\end{array}$ \\
\hline & $\begin{array}{l}\text { (Supply/Value Chain) Collaboration in } \\
\text { terms of suppliers and/or financial partners } \\
\text { Thderstanding and Addressing the Needs of }\end{array}$ & Hart and Dowell 2010 \\
\hline & (Supply Chain) Monitoring & $\begin{array}{l}\text { Klassen and Vereecke 2012; Glavas } \\
\text { and Mish 2015 }\end{array}$ \\
\hline & Manage the various external stakeholders & $\begin{array}{l}\text { Spear et al. 2013; Tracey et al. } \\
\text { 2011; Torugsa et al. 2012 }\end{array}$ \\
\hline $\begin{array}{l}\text { Consistency (of } \\
\text { behavior) }\end{array}$ & $\begin{array}{l}\text { Manage conflicting institutional goals, } \\
\text { structures and processes }\end{array}$ & Mission-driven approach (over time) \\
\hline & Pache and Santos 2012 \\
\hline & Glavas and Mish 2015 \\
\hline
\end{tabular}




\section{APPENDIX A}

\section{YUNUS SOCIAL BUSINESS PROFILE, Source: YSB (2014, pp. 3-5).}

\section{Principles of Social Business:}

1. Goal: To solve social or environmental problems

2. Financial and economic sustainability

3. Investors repaid; no further private financial return

4. Profit funds expansion, improvements or seeding other social businesses

5. Environmentally conscious

6. Market wages; better working conditions

7. Do it with joy

YSB applies business approaches to the world of social development. It has developed an innovative Incubator Fund methodology which bridges the gap between social businesses and social investors and donors. While the Incubator searches, coaches and selects social businesses, the Fund provides debt and equity financing to the businesses after a thorough due diligence process. While a traditional investor invests for financial gain, a Social Investor invests to benefit society. A Social Investor's goal is to maximize social return on his or her investment and is thus motivated to support the most effective social businesses. By investing in a Social Business Incubator Fund, the Social Investor benefits from standardized annual and semi-annual reports that detail both financial and social impact performance. The Social Investor will recoup up to the full nominal value of his or her initial investment. All profits from the social businesses are committed to be recycled into new social businesses.

The Fund receives capital from donors and investors. After a thorough due diligence process, the Fund invests this capital into social businesses that have been selected and prepared by the Incubator. As the social businesses pay back the capital, the Fund reinvests it into other social businesses, and/or returns it to philanthropic investors in proportion to their share of the total capital contributed, up to the nominal value of his or her initial investment.

The incubator is responsible for searching and creating social business opportunities and helping the social businesses develop a strong and coherent business plan. It also provides coaching and capacity building to social business entrepreneurs, allowing access to useful networks that help them expand their businesses.

1. Searching and Creating Social Business Opportunities

YSB receives hundreds of social business plans on an annual basis. The Incubator is responsible for screening the plans and moving forward with a handful that demonstrate the highest potential. In order to attract entrepreneurs, the Incubator holds Social Business Plan competitions, public events and workshops.

\section{Developing Social Business Plans}

Once pre-selected, the Incubator works with the business to improve the social business plan and prepare the business for investment. At this stage, the Incubator will focus on whether the social business will be financially self-sustainable and determine how to maximize its social impact.

\section{Training, Coaching and Capacity Building}

Pre- and post-investment, the Incubator continuously seeks to broaden the skill sets and capabilities of its entrepreneurs. This includes personal coaching and courses on topics such as business accounting or technical industry-specific topics. The Incubator is supported by a network of corporate pro-bono partners.

\section{Networks}

The Incubator provides access to its local and international networks of potential buyers, partners and experts that lend support to the social businesses. 